RECEIVED

MOV 061997

OSTI
OAK RIDGE

NATIONAL

LABORATORY

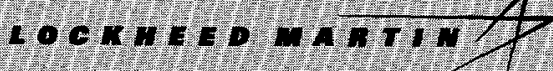

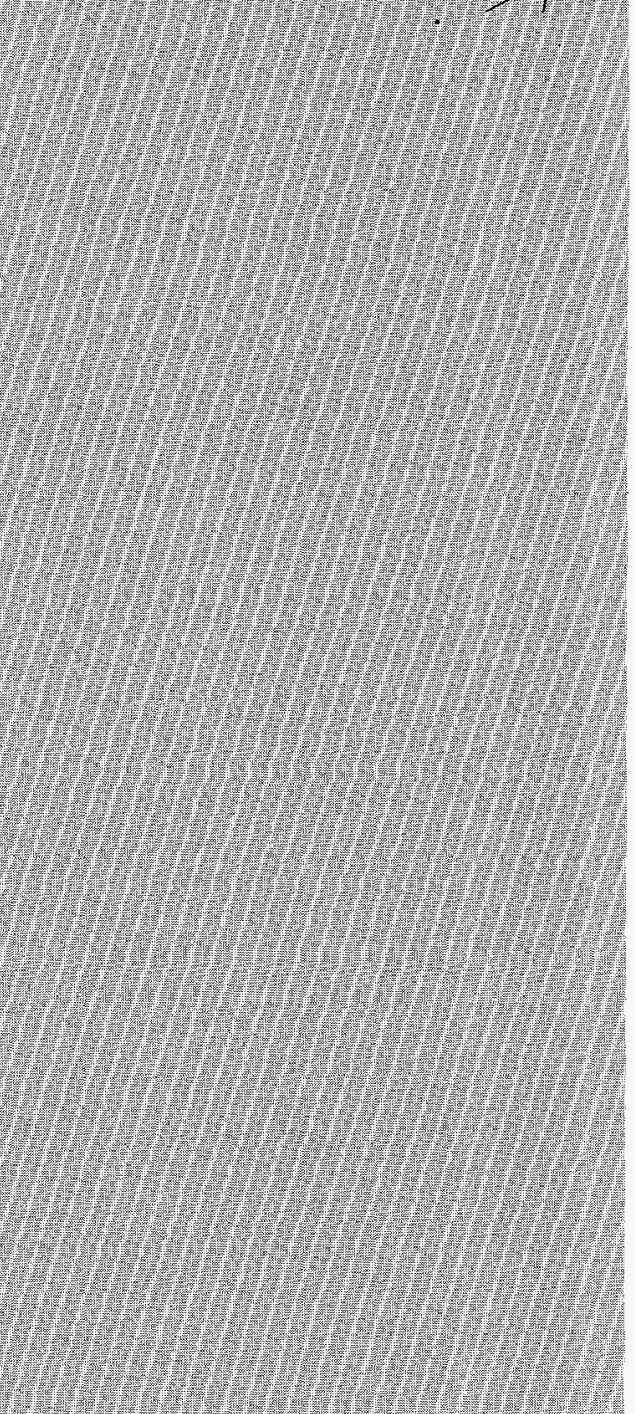

WANAGED AND OPERATED BY

LOCKHEEO MARTN ENERGY RESEARCH CORPORATION FOR THE UNTEO STATES OEPARTIEET OF ENEAGY
John R. Trabalka 


\title{
Buried Transuranic Wastes at ORNL: Review and Reconciliation of Past Estimates
}

\author{
John R. Trabalka
}

September 1997

Prepared by the

OAK RIDGE NATIONAL LABORATORY

Oak Ridge, Tennessee 37831 managed by

LOCKHEED MARTIN ENERGY RESEARCH CORP. for the

U.S. DEPARTMENT OF ENERGY under contract DE-AC05-96OR22464 


\section{DISCLAMMER}

This report was prepared as an account of work sponsored by an agency of the United States Government. Neither the United States Government nor any agency thereof, nor any of their employees, makes any warranty, express or implied, or assumes any legal liability or responsibility for the accuracy, completeness, or usefulness of any information, apparatus, product, or process disclosed, or represents that its use would not infringe privately owned rights. Reference herein to any specific commercial product, process, or service by trade name, trademark, manufacturer, or otherwise does not necessarily constitute or imply its endorsement, recommendation, or favoring by the United States Government or any agency thereof. The views and opinions of authors expressed herein do not necessarily state or reflect those of the United States Government or any agency thereof. 


\section{DISCLAIMER}

Portions of this document may be illegible electronic image products. Images are produced from the best available original document. 


\section{CONTENTS}

LIST OF FIGURES

iv

LIST OF TABLES

$\mathrm{v}$

ABBREVIATIONS, ACRONYMS, AND INITIALISMS $\ldots \ldots \ldots \ldots \ldots \ldots \ldots \ldots \ldots$ vi

ABSTRACT $\ldots \ldots \ldots \ldots \ldots \ldots \ldots \ldots \ldots \ldots \ldots \ldots \ldots \ldots \ldots \ldots \ldots \ldots$

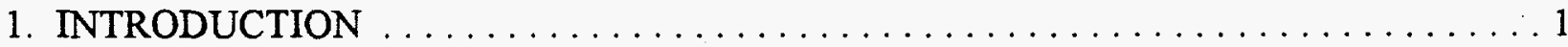

1.1 HISTORICAL BACKGROUND $\ldots \ldots \ldots \ldots \ldots \ldots \ldots \ldots \ldots \ldots \ldots \ldots$

1.1.1 Transuranic Waste Definitions and Management Requirements . . . . . . . . 1

1.1 .2 Rationale . . . . . . . . . . . . . . . . . . . . . . . . . 3

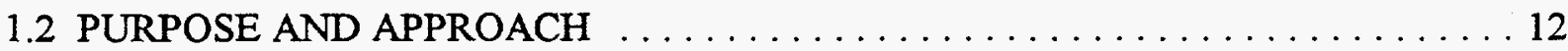

2. REVIEW OF PAST ESTIMATES $\ldots \ldots \ldots \ldots \ldots \ldots \ldots \ldots \ldots \ldots \ldots \ldots \ldots$

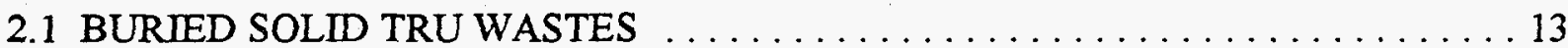

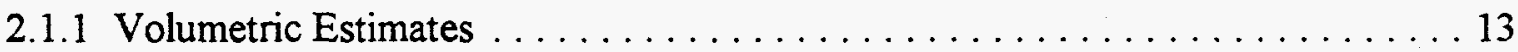

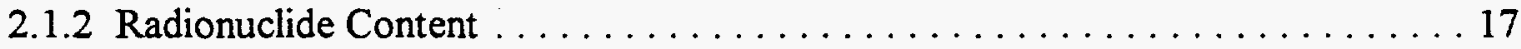

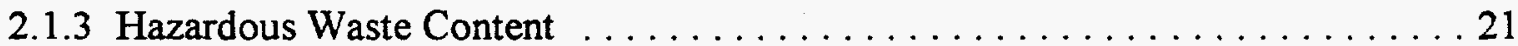

2.2 TRU-CONTAMINATED SOILS PROXIMATE TO

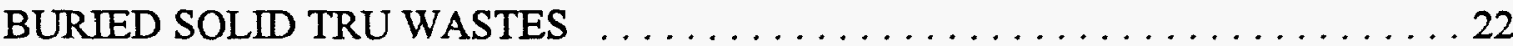

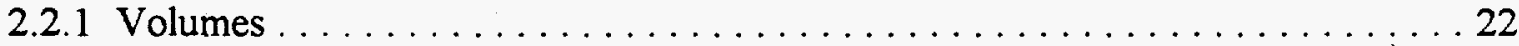

2.2 .2 Radionuclide and Hazardous Waste Content . . . . . . . . . . . . 23

2.3 TRU-CONTAMINATED SOILS/WASTE MATRICES

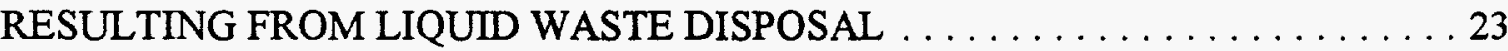

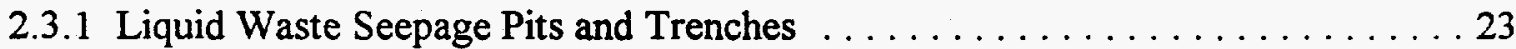

2.3.2 Subsurface Grout Sheets Produced by the New Hydrofracture Facility . . . . . . 26

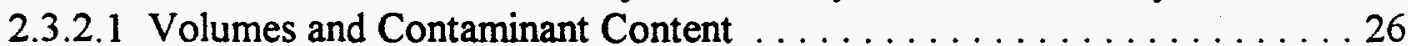

2.4 OTHER POTENTIAL SOURCES OF "BURIED" TRU WASTES . . . . . . . . . . . 29

3. CONCLUSIONS AND RECOMMENDATIONS $\ldots \ldots \ldots \ldots \ldots \ldots \ldots \ldots \ldots \ldots$

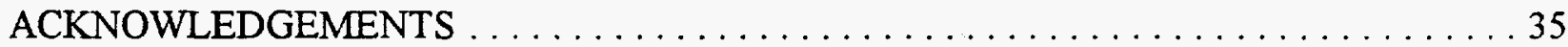

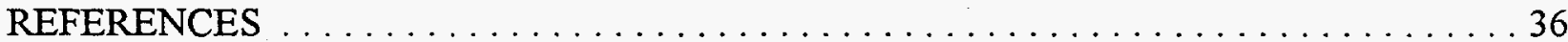

APPENDIX A. ADDITIONAL REFERENCE MATERIALS . . . . . . . . . . . A-1

APPENDIX B. DESCRIPTION OF RH-TRU WASTES FROM THE REDC $\ldots \ldots \ldots \ldots$. . 


\section{LIST OF FIGURES}

Figure

Page

1 Locations of potential storage and disposal sites for transuranic wastes at ORNL . . . .4

2 Locations of transuranic waste storage and disposal sites in the north area of Solid Waste Storage Area $5 \ldots \ldots \ldots \ldots \ldots \ldots \ldots \ldots$ 


\section{LIST OF TABLES}

Table

1 Sources of uncertainty or variation in estimates of

buried transuranic wastes at ORNL

2 Recorded radioactivity ( $\mathrm{Ci}$ ) of principal radionuclides in materials stored or disposed of in Solid Waste Storage Area (SWSA) 5 and classified as RH-TRU wastes in 1989

3 Selected comparisons of original input on radionuclide content provided by TRU waste generators with corresponding data in current ORNL Waste Tracking System data base

4 Estimates of buried waste inventories in Solid Waste Storage Areas 1-5 at ORNL made using back-extrapolations and accountability records

5 Recorded radioactivity ( $\mathrm{Ci}$ ) and internal volume of solid TRU waste containers buried in Solid Waste Storage Area (SWSA) 5 at ORNL, updated from recent data evaluation activities

6. Radioactivity and volumes of liquid low-level wastes (LLW) discharged to the Seepage Pits and Trenches at ORNL

7 Recorded radioactivity ( $\mathrm{Ci}$ ) and volume in TRU-waste sludge-grout mixtures injected at the New Hydrofracture Facility at ORNL, updated from recent data evaluation activities

8 Estimates of buried TRU waste inventories produced by liquid or solid radioactive waste disposal at ORNL 32 
$\begin{array}{ll}\text { ATN No. } & \text { Attention number (identifier used for tracking waste containers at ORNL) } \\ \text { CERCLA } & \text { Comprehensive Environmental Response, Compensation, and Liability Act } \\ \text { CFR } & \text { U. S. Code of Federal Regulations } \\ \text { CH } & \text { contact-handled } \\ \text { DOE } & \text { Department of Energy } \\ \text { EPA } & \text { Environmental Protection Agency } \\ \text { ER } & \text { Environmental Restoration } \\ \text { HEPA } & \text { high-efficiency particulate air } \\ \text { HFIR } & \text { High Flux Isotopes Reactor } \\ \text { LLW } & \text { low-level radioactive wastes } \\ \text { MVSTs } & \text { Melton Valley Storage Tanks } \\ \text { NRC } & \text { Nuclear Regulatory Commission } \\ \text { ORNL } & \text { Oak Ridge National Laboratory } \\ \text { ORR } & \text { Oak Ridge Reservation } \\ \text { REDC } & \text { Radiochemical Engineering Development Center } \\ \text { RCRA } & \text { Resource Conservation and Recovery Act } \\ \text { RH } & \text { remote-handled } \\ \text { SC } & \text { special-case } \\ \text { SS } & \text { stainless steel } \\ \text { SWIMS } & \text { Solid Waste Information Management System } \\ \text { SWSA } & \text { Solid Waste Storage Area } \\ \text { TRU } & \text { transuranic } \\ \text { WAC } & \text { waste acceptance criteria } \\ \text { WIPP } & \text { Waste Isolation Pilot Plant } \\ \text { WTS } & \text { Waste Tracking System }\end{array}$ 


\begin{abstract}
Inventories of buried (generally meaning disposed of transuranic (TRU) wastes at Oak Ridge National Laboratory (ORNL) have been estimated for site remediation and waste management planning over a period of about two decades. Estimates were required because of inadequate waste characterization and incomplete disposal records. For a variety of reasons, including changing definitions of TRU wastes, differing objectives for the estimates, and poor historical data, the published results have sometimes been in conflict. The purpose of this review was (1) to attempt to explain both the rationale for and differences among the various estimates, and (2) to update the estimates based on more recent information obtained from waste characterization and from evaluations of ORNL waste data bases and historical records. The latter included information obtained from an expert panel's review and reconciliation of inconsistencies in data identified during preparation of the ORNL input for the third revision of the Baseline Inventory Report for the Waste Isolation Pilot Plant. The results summarize our current understanding of the relationship between past estimates of buried TRU wastes and provide the most up-to-date information on recorded burials thereafter. The limitations of available information on the latter and thus the need for improved waste characterization are highlighted.
\end{abstract}




\section{INTRODUCTION}

\subsection{HISTORICAL BACKGROUND}

Although transuranic (TRU) wastes are now defined as those containing alpha-emitting transuranium radionuclides with half-lives $>20 \mathrm{y}$ in concentrations $>100 \mathrm{nCi} / \mathrm{g}$ [U. S. Department of Energy (DOE) Order 5820.2A, September 26, 1988; Waste Isolation Pilot Plant (WIPP) Land Withdrawal Act (LWA), 1992; 40 CFR 191 regulations, 1985 and 1994 revisions], this has not always been the case. Prior to 1970, there was no "transuranic" waste classification. Radioactive waste contaminated with TRU elements was classified as low-level waste (LLW) and disposed of by shallow land burial (DOE 1988). The dividing line between contact-handled (CH-) and remote-handled (RH-) wastes was (and still is) an external dose rate of $200 \mathrm{mrem} / \mathrm{h}$.

\subsubsection{Transuranic Waste Definitions and Management Requirements}

In 1970, the U.S. Atomic Energy Commission established a TRU waste classification, and any solid waste contaminated to $>10 \mathrm{nCi} / \mathrm{g}$ was to be segregated and stored, pending a disposal method that was yet to be determined. In 1982, the U.S. Nuclear Regulatory Commission (NRC) defined the concentration boundary between LLW and Greater-Than-Class-C LLW containing TRU constituents as $100 \mathrm{nCi} / \mathrm{g}$. A $100 \mathrm{nCi} / \mathrm{g}$ boundary between $\mathrm{LLW}$ and TRU wastes was subsequently adopted by the DOE in 1984 (DOE Order 5820.2, Waste Management, February 6, 1984; ORNL 1984; Everette et al. 1988).

The DOE definition of what constitutes a "TRU-waste" radionuclide has also evolved with time. In DOE Order 5820.2 (1984), TRU wastes were defined by the concentrations "at the end of institutional control." Although wastes containing ${ }^{244} \mathrm{Cm}$ (or ${ }^{241} \mathrm{Pu}$, a beta emitter; half-life $=14.4$ y) are not TRU wastes regardless of concentration under the current definition, this was not true in 1984. Wastes containing ${ }^{244} \mathrm{Cm}$ in excess of $36,300 \mathrm{nCi} / \mathrm{g}$ were classified as TRU wastes because radioactive decay over a nominal institutional control period $(200 \mathrm{y})$ would result in concentrations of its daughter $\left({ }^{240} \mathrm{Pu}\right.$; half-life $\left.=6570 \mathrm{y}\right)$ greater than $100 \mathrm{nCi} / \mathrm{g}$. The $80,000 \mathrm{Ci}$ inventory of ${ }^{241} \mathrm{Pu}$ in ORNL's stored CH-TRU wastes (Arakawa et al. 1994) would decay to 2670 $\mathrm{Ci}$ of $432-\mathrm{y}^{241} \mathrm{Am}$ over that same time interval. Some of these wastes would thus have been classified as TRU wastes under the 1984 DOE definition even if they had not contained any other TRU isotopes. It is not currently known how much of ORNL's TRU waste (buried or stored) would be reclassified as LLW because of this change in definition.

The current DOE waste management Order $(5820.2 \mathrm{~A}$, September 26,1988$)$ also permits Field Offices to "determine that other alpha contaminated wastes, peculiar to a specific site, must be managed as transuranic waste." This determination was to be based on uniqueness to a given site (e.g., ${ }^{233} \mathrm{U},{ }^{244} \mathrm{Cm}$, and ${ }^{252} \mathrm{Cf}$ at $\mathrm{ORNL}$ ) and management concerns (difficulties in assay, need for special handling). Past versions of DOE waste management requirements have included similar 
provisions. ORNL has managed wastes containing ${ }^{244} \mathrm{Cm}$ and ${ }^{252} \mathrm{Cf}$ [originating primarily from the Radiochemical Engineering Development Center (REDC)] as TRU wastes since the late 1960s, and began managing ${ }^{233} \mathrm{U}$ as a "TRU" waste radionuclide in fiscal year (FY) 1974 at the direction of the DOE-Oak Ridge Operations Office.

However, such site-specific "determinations" of TRU radionuclide status are being eliminated in the revised DOE Order on waste management [435.1; see draft Implementation Guide (G 435.1, dated February 28, 1997)] in order to promote a definition of TRU waste consistent with that adopted by the U.S. Environmental Protection Agency (EPA) in the 40 CFR 191 regulations. The TRU-waste definition in current federal regulations and in the WIPP LWA (Sect. 1.1) does not include radionuclides such as ${ }^{233} \mathrm{U},{ }^{244} \mathrm{Cm}$, and ${ }^{252} \mathrm{Cf}$. Thus, wastes containing "only" these radionuclides would not be considered TRU wastes. In order to be classified as TRU wastes, ${ }^{233} \mathrm{U},{ }^{244} \mathrm{Cm}$, and ${ }^{252} \mathrm{Cf}$ wastes must contain co-contaminants with half-lives $>20 \mathrm{y}$ in concentrations $>100 \mathrm{nCi} / \mathrm{g}$. The impacts of this change in definition on classification of ORNL's buried wastes will be examined further in Sect. 1.1.2.

Because the TRU-waste definition was based on a concentration $>10 \mathrm{nCi} / \mathrm{g}$, rather than $>100$ $\mathrm{nCi} / \mathrm{g}$, from 1970 through early 1984, some buried wastes at ORNL may not be TRU wastes as currently defined, based on initial concentration alone. It has been estimated that $10 \%$ of ORNL's buried TRU waste volume would fail to meet the $100 \mathrm{nCi} / \mathrm{g}$ criterion (King 1985). However, it is not possible to either confirm or deny this estimate based on current information.

The definition of what constitutes "buried TRU waste" has also evolved with time. The most prevalent interpretation is given below:

"Waste disposed of prior to the decision to retrievably store the waste and which may contain TRU contamination is referred to as "buried transuranic-contaminated waste" (BTW). This waste is primarily in two forms: Buried solid waste and contaminated soil. Contaminated soil falls into two categories: Soil contaminated by being in contact with solid waste, and soil contaminated by liquid waste injection" (emphasis added) (Everette at al. 1988).

However, the definition given above has sometimes been interpreted to include only the two forms described in the quote and to exclude all wastes disposed of after FY 1970, even if these otherwise meet the definition. Typically, the FY 1970 cutoff point has not been rigidly maintained for cases where disposals took place within a few years after 1970 (i.e., up to 1977 at ORNL).

In the early 1990s, the buried-TRU-waste definition was temporarily relaxed, and ORNL TRU wastes disposed of during the 1980s were included in the DOE Integrated Data Base (IDB). In this particular case, the wastes were liquid LLW or TRU-waste sludges, which were mixed with grout and injected deep underground by hydrofracturing (ORNL 1994a). However, most of the information on wastes injected by hydrofracturing was deleted from the IDB after one year (see Sect. 2.3.2). 
The principal ORNL sites that have previously been considered to contain buried TRU wastes are shown in Fig. 1. Storage and disposal areas in Solid Waste Storage Area (SWSA) 5 North are shown in Fig. 2. Shallow-land burial trenches were used for solid waste disposal. High-activity liquid LLW (originally classified as intermediate-level waste) was disposed of initially via seepage from pits or trenches (1951-1966) and later by hydrofracturing (see ORNL 1986, 1987a).

\subsubsection{Rationale for Study}

Inventories of buried (generally meaning disposed of) TRU wastes at Oak Ridge National Laboratory (ORNL) have been estimated for site remediation and waste management planning over a period covering about two decades. Estimates were required because records for early solid waste disposals were destroyed by fire in the early 1960s (Coobs and Gissel 1986; H\&R 1997), and waste characterization has generally been very limited. For a variety of reasons, including changing definitions of TRU wastes, differing objectives for the estimates, and poor historical data - for TRU wastes as a whole but particularly for "buried" TRU wastes - the published results have sometimes been in conflict. Some of the reasons for conflicts among the various estimates are shown in Table 1.

An examination of the data in Table 2 illustrates the basis for most of the concerns identified in Table 1. Table 2 is a summary of a detailed data set, assembled from the ORNL Solid Waste Information Management System (SWIMS) TRU Database by Stewart et al. (1989), which was used as primary ORNL input on RH-TRU wastes for the Baseline Inventory Reports (BIRs) for the WIPP prior to 1996. These same data were also used to estimate both buried and stored waste inventories for the CERCLA Remedial Investigation Report for Waste Area Grouping 5, which contains Solid Waste Storage Area (SWSA) 5 (ORNL Environmental Restoration Program 1995).

Only the RH-TRU waste casks identified in row (e) of Table 2 were considered irretrievable (= disposed of) in the 1989 report. The materials in row (c) of Table 2 were thus reported as "stored" for the WIPP-BIRs before 1996, even though the containers were placed in trenches (see Fig. 2) which were then backfilled with concrete: The same practice used to dispose of the 108 concrete casks identified in row (e) of the Table. In fact, inventories associated with both of these disposal areas were the post-1969 TRU-waste data used during the late 1970s and early 1980 s to make estimates of pre-1970 buried-TRU-waste volumes via back-extrapolation (see Sect. 2.1.1).

The number of containers emplaced in the 4-trench disposal area in SWSA 5 North (Fig. 2) is given as 59 in row (c) of Table 2. Currently, there are at least 63 containers known to have been disposed of at this site (see Sect. 2.1.1). The primary reason for the difference is that five waste boxes (ORNL ATN Nos. ${ }^{a} 302-305$, and 546, respectively), reportedly stored in Trench 2 of the

\footnotetext{
${ }^{a}$ The ATN (attention) number is an identifier used for tracking waste containers at ORNL:
} 
ORNL DWG 97A-268

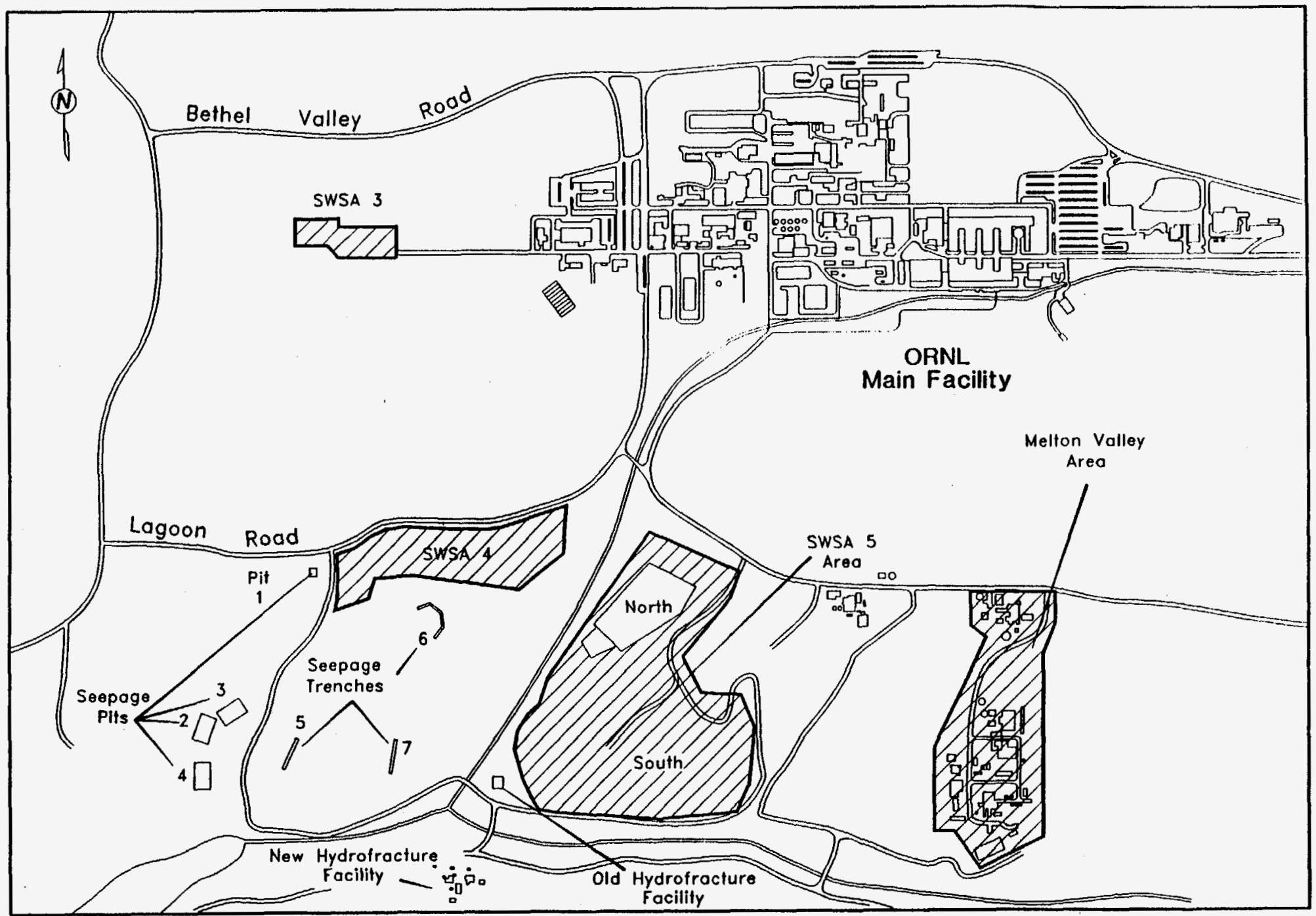

Fig. 1. Locations of potential storage and disposal sites for transuranic wastes at ORNL. 

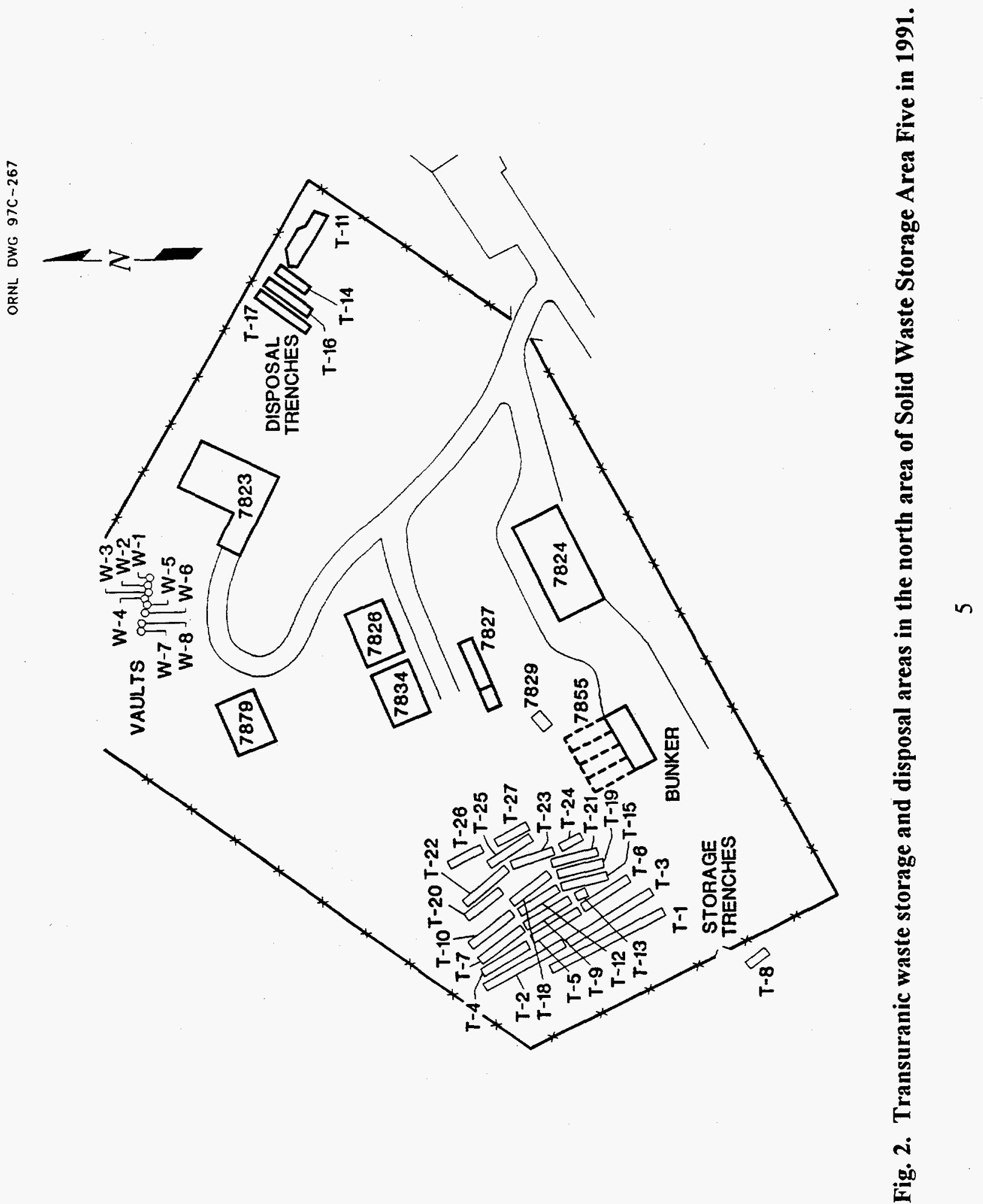
Table 1. Sources of uncertainty or variation in estimates of buried transuranic wastes at $\mathrm{ORNL}^{\mathrm{a}}$

- Inadequate early records and lack of formal waste characterization leading to:

-- Initial use of back-extrapolations and accountability records to produce estimates, which were later dropped because of inherently high uncertainties

-- $\quad$ Underreporting of many radionuclides and widespread reporting of $\leq$ values by waste generators

-- Use of surrogates for missing or $\leq$ values for RH-TRU wastes before 1979

- Differences in interpretation of ORNL inventory data

-- $\quad$ Changes in status: From stored to buried, and vice versa

-- Errors in container counts, internal volumes, and/or radioactivity data

-- Uncertainties in dates or locations of waste burials

- Poor documentation of basis for some estimates or revisions

- Changes in ORNL TRU waste characteristics over time

- Corrections or adjustments to account for changes in the definition of TRU waste

-- Increase in concentration limit from $10 \mathrm{nCi} / \mathrm{g}$ to $100 \mathrm{nCi} / \mathrm{g}$

-- Temporary inclusion of isotopes not now addressed in the TRU waste definitions in either the WIPP Land Withdrawal Act of 1992 or 40 CFR 191 regulations

- $\quad$ Temporary inclusion of spent nuclear fuel materials, etc.

- Changes in interpretation of the DOE definition of "buried" TRU waste

- $\quad$ Temporary inclusion of wastes (e.g., hydrofracturing wastes) based on interpretation that was current at the time a given estimate was generated

- Typographical errors in input data for the ORNL Solid Waste Information Management System, ORNL Waste Tracking System, DOE Integrated Data Base, or the WIPP Baseline Inventory Reports

- Use of new data from recent attempts to characterize newly generated wastes

${ }^{a} \mathrm{ORNL}=$ Oak Ridge National Laboratory; $\mathrm{RH}=$ remote handled; TRU = transuranic; DOE = U. S. Department of Energy; CFR = U. S. Code of Federal Regulations; WIPP = Waste Isolation Pilot Plant. 
Table 2. Radioactivity (Ci) of principal radionuclides in RH-TRU wastes in SWSA $5^{\mathrm{a}}$

\begin{tabular}{|c|c|c|c|c|c|c|c|c|c|}
\hline Storage/disposal area & $\begin{array}{c}\text { Dates } \\
\text { emplaced }\end{array}$ & ${ }^{239} \mathrm{Pu}^{\mathrm{b}}$ & ${ }^{241} \mathrm{Am}$ & ${ }^{244} \mathrm{Cm}$ & ${ }^{252} \mathrm{Cf}$ & ${ }^{233} \mathrm{U}$ & ${ }^{232} \mathrm{Th}$ & $\begin{array}{l}\text { Fission } \\
\text { prods. }\end{array}$ & Unident. \\
\hline \multicolumn{10}{|c|}{ SWSA 5 North } \\
\hline $\begin{array}{l}\text { (a) } 84 \text { RH-TRU waste casks } \\
\text { in storage bunker }\end{array}$ & $1979-87$ & 0.54 & 24.0 & 284. & 21.9 & 1.10 & ---- ${ }^{c}$ & $-\cdots-$ & ----- \\
\hline $\begin{array}{l}\text { (b) } 215 \text { RH-TRU waste } \\
\text { containers in } 22 \text {-trench } \\
\text { storage area }(7802 \mathrm{~N})^{d}\end{array}$ & $1970-81$ & 5.88 & 10.6 & 82.6 & 24.0 & 2.46 & ----- & 88.2 & 0.45 \\
\hline $\begin{array}{l}\text { (c) } 59 \text { TRU waste containers } \\
\text { in 4-trench disposal area }\end{array}$ & $1970-77$ & 4.51 & 0.70 & 62.9 & 0.01 & --.-- & $-\cdots-$ & 13.1 & 126. \\
\hline (d) 8 spent-fuel storage wells & $1972-75$ & 16.6 & ----- & $<0.01$ & $\cdots-$ & ----- & $3.0^{\mathrm{f}}$ & ---- & 438. \\
\hline \multicolumn{10}{|c|}{ SWSA-5 South } \\
\hline $\begin{array}{l}\text { (e) } 108 \text { RH-TRU waste } \\
\text { casks in } 8 \text { disposal trenches }^{8}\end{array}$ & $1970-74$ & 18.1 & 3.24 & 26.9 & 8.68 & ----- & ----- & 0.01 & 96. \\
\hline (f) 2 SC-LLW storage vaults ${ }^{h}$ & $1963-69$ & ---- & ---- & ----- & --- & $-\cdots$ & ---- & $-\cdots$ & ----- \\
\hline Totals (a-f) & & 45.6 & 37.7 & 456. & 54.6 & 3.56 & $3.0^{f}$ & 101 & 660. \\
\hline
\end{tabular}


${ }^{a}$ Source: Report by Stewart et al. (1989) on materials stored or disposed of in Solid Waste Storage Area (SWSA) 5 and classified as remote-handled transuranic (RH-TRU) wastes in 1989. Reporting of radionuclides was typically incomplete, particularly for RH-TRU waste casks. Data typically are rough estimates by waste generators or surrogates recorded by waste management personnel rather than results from measurements (see text).

${ }^{\mathrm{b}}$ Includes ${ }^{240} \mathrm{Pu}$.

Not reported.

${ }^{d} 200$ casks, 13 boxes, and two 55 -gal drums were reportedly placed in trenches that were backfilled with earth. Five boxes and several casks reported as stored in this trench area were actually disposed of in the trench areas identified in rows (c) and (e) of the Table (see footnote immediately below and discussion in text).

${ }^{\mathrm{e}} 58$ boxes and 1 calutron tank, containing primarily contact-handled TRU wastes, were placed in trenches, encased in concrete, and then covered with soil. One box was not disposed of as reported and is currently in storage, but five boxes reportedly stored in Trench 2 in the 7802N area were actually disposed of in this area, bringing the total to 63. Some wastes were apparently stored for several years prior to actual disposal, which occurred during 1975-1977 (see text).

Value is incorrect; material is contained in 6" stainless steel can; was likely $3 \mathrm{~kg}$, rather than $3 \mathrm{Ci}$.

${ }^{B_{A}}$ r revised inventory for this area was provided by Arakawa et al. (1994). However, several containers included in the latter were not generated until 2 years after the last disposal trench in this area had closed, and one cask was inadvertently left off the inventory. After making the necessary adjustments to the inventory, the number of containers was reduced to 106 and the number of disposal trenches was reduced from 8 to 5 (see text).

${ }^{\mathrm{h}} \mathrm{SC}-\mathrm{LLW}=$ special-case LLW. Inventory in the 2 vaults reportedly $1,100 \mathrm{Ci}$ of ${ }^{60} \mathrm{Co}$ and $60,000 \mathrm{Ci}$ of ${ }^{110 \mathrm{~m}} \mathrm{Ag}$, respectively. 
22-trench 7802N Area [Fig. 2; row (b) of Table 2], were actually disposed of in Trenches 11 and 16 of the 4-trench disposal area. A number of waste containers were apparently stored temporarily in Trench 2 before it was backfilled with earth but then were moved to one of the disposal trenches. However, the subsequent transfer was not always recorded. The correct locations were confirmed from a map of container locations in Trench 11 that was attached to the disposal operations logbook for the period in question.

Several concrete casks (ATN Nos. 205 and 318) also were stored temporarily in "Trench 2" and then disposed of in one of the trenches located in SWSA 5 South [i.e., row (e) of Table 2]. However, these were included in the "stored" inventory in the $7802 \mathrm{~N}$ Area [part of row (b) in Table 2] in 1989. In another case, a cask (ATN No. 882) and a waste box emplaced in SWSA 5 North that were included on the inventory of disposal trenches in SWSA 5 South were not even generated until 2 years after the last such disposal trench had been closed. When several such errors were corrected, the number of post-1969 disposal trenches in SWSA 5 South was reduced from 8 to 5 , the number of containers disposed of was reduced from 108 to 106, and the range of dates for such disposals was narrowed from 1970-1974 to 1970-1972.

The RH-TRU waste category has at times included a variety of difficult-to-certify or -classify waste materials (sometimes referred to as special-case wastes) if these materials contained TRU constituents. For example, small quantities of irradiated nuclear fuel originating from research activities [i.e., row (d) of Table 2; also see Table 2 of ORNL (1987b)] have been managed as RHTRU wastes, subject to certain restrictions, in the absence of other management options. Current plans, however, are to dispose of the materials identified in row (d) of Table 2 with other spent nuclear fuel residues from ORNL. The special-case LLW in the 2 storage vaults identified in row (f) of Table 2 has no discernable TRU waste content based on findings of the 1996 TRU Waste Data Review at ORNL, and these materials have accordingly been reclassified as LLW.

Examining the differences in composition of TRU wastes among the sites identified in Table 2 provides an indication of the potential errors introduced by using post- 1969 data to estimate the inventories of wastes buried before 1970. This is first shown by comparing the transuranic composition of different types of wastes disposed of after 1969. Mainly CH-TRU wastes were emplaced in the 4-trench area in SWSA 5 North while RH-TRU wastes were buried in the trenches in SWSA 5 South [cf data for row (c) with row (e) in Table 2]. The reported ${ }^{239} \mathrm{Pu}$ and ${ }^{241} \mathrm{Am}$ content in RH-TRU waste casks was much greater than that in the CH-TRU wastes even though the RH-TRU waste volume was less than half: $176 \mathrm{~m}^{3}$ vs $393 \mathrm{~m}^{3}$ (see Sect. 2.1 .1 for details). Changes over time in radionuclide composition of TRU wastes are illustrated by the differences in reported transuranic content in RH-TRU wastes stored or disposed of in SWSA 5 [rows (e), (b), and (a), respectively, in Table 2]. A clear trend toward reporting of lowered ${ }^{239} \mathrm{Pu}$ content and increased ${ }^{241} \mathrm{Am},{ }^{244} \mathrm{Cm}$, and ${ }^{252} \mathrm{Cf}$ content over time is shown by these data. The trend for the first three isotopes is evident even without adjusting for differences in the number of containers among the three sites. The reason for this trend is that $R \& D$ on fuel reprocessing and $\mathrm{Pu}$ separations was on the decline over the period while transplutonium isotope production at the Radiochemical Engineering Development Center (REDC), the primary source of RH-TRU wastes 
at ORNL, was on the upswing (Jolley et al. 1994). Thus, both the mix of RH- and CH-TRU wastes and the radionuclide content in TRU wastes disposed of after 1969 was significantly different than that disposed of prior to 1970 .

One has to exercise caution in drawing conclusions based on the information in Table 2 because of flaws in the primary data. The principal flaw is that radionuclide inventory data typically were crude estimates rather than results derived from measurements. Often only isotopes of primary interest to the waste generators were reported. In many instances, $\leq$ values only were provided. However, the $\leq$ sign was not recorded when values were transcribed into the data bases for either the SWIMS or its successor, the Waste Tracking System (WTS). These problems are particularly evident in the waste disposal records for the primary TRU-waste generating site, the REDC, at which the typical practice was to report only estimates of ${ }^{244} \mathrm{Cm}$ and/or ${ }^{252} \mathrm{Cf}$ activity, even though many other TRU isotopes, along with a variety of fission products, were present in the wastes. Characterization of wastes from the REDC has been limited because of the complexity and heterogeneity of the waste streams, the high costs of sampling and destructive assay, high radiation levels associated with $\mathrm{RH}$-TRU wastes, and the absence of an effective nondestructive assay technology (Nguyen, Miller, and Downing 1997).

However, comparisons of data on original waste disposal forms (UCN-2822) with that in the SWIMS or WTS data bases or in the report by Stewart et al. (1989) reveal yet another problem with the radionuclide inventory data for REDC wastes. Most of the data for RH-TRU wastes generated prior to 1979 were systematically altered such that there is no correspondence between the original input data and that in the data base(s). This included both alteration of generatorsupplied values and creation of new values for missing data: Examples of which are shown in Table 3. These alterations affect the inventories in rows (b) and (e) of Table 2. In most cases, the changes resulted in an increase in the estimated radioactivity in the wastes, when compared with the information provided by the waste generators. However, documentation of the rationale and methodology for the changes was either not developed or has been lost. Without knowing why or how the original data were modified, therefore, it is not possible to determine whether the changes were either justified or reasonable. Because the REDC had become the dominant source of TRU wastes - and buried TRU wastes - at ORNL by 1970, the uncertainties in the waste profile for the REDC provide further limits on the use of post-1969 inventory data in reconstructing the composition of buried-TRU-waste legacies.

These uncertainties and the changing definition of TRU wastes (see Sect. 1.1.1) led to the realization in 1994 that it could not be demonstrated that the majority of ORNL's TRU wastes newly generated, stored, or disposed of - actually met the TRU waste definition. Based on the limited information available (e.g., waste disposal records), it appeared that the bulk of the post1969 wastes could be alpha-contaminated LLW rather than TRU wastes. This realization and the resulting uncertainty in the classification of wastes buried in SWSA 5 were highlighted in the CERCLA Remedial Investigation Report for Waste Area Grouping 5 at ORNL (ORNL Environmental Restoration Program 1995). 
Table 3. Selected comparisons of recorded radionuclide content provided by TRU waste generators with corresponding data in current ORNL Waste Tracking System data base

\begin{tabular}{|c|c|c|c|c|}
\hline \multirow{3}{*}{$\begin{array}{l}\text { Container } \\
(\text { ATN) No. } \\
00003\end{array}$} & \multirow{3}{*}{$\begin{array}{l}\begin{array}{c}\text { Date on } \\
\text { UCN-2822 } \\
\text { form }\end{array} \\
10 / 11 / 70\end{array}$} & \multicolumn{3}{|c|}{ Radionuclide inventory in container } \\
\hline & & UCN-2822 record & Data bas & se record \\
\hline & & Trans $\mathrm{Pu}$ & $\begin{array}{l}{ }^{244} \mathrm{Cm} \\
{ }^{239} \mathrm{Pu}\end{array}$ & $\begin{array}{l}1.00 \mathrm{Ci} \\
0.000 \mathrm{Ci}\end{array}$ \\
\hline 00012 & $11 / 20 / 70$ & ${ }^{244} \mathrm{Cm}$ & ${ }^{244} \mathrm{Cm}$ & $1.00 \mathrm{Ci}$ \\
\hline 00026 & $01 / 11 / 71$ & ${ }^{244} \mathrm{Cm}, \mathrm{Cs}$ & $\begin{array}{l}{ }^{244} \mathrm{Cm} \\
{ }^{137} \mathrm{Cs}\end{array}$ & $\begin{array}{l}0.25 \mathrm{Ci} \\
0.009 \mathrm{Ci}\end{array}$ \\
\hline 00110 & $06 / 09 / 71$ & $\mathrm{Cm}, \mathrm{Cf}<200 \mathrm{~g}$ & $\begin{array}{l}{ }^{244} \mathrm{Cm} \\
{ }^{252} \mathrm{Cf}\end{array}$ & $\begin{array}{l}0.25 \mathrm{Ci} \\
0.17 \mathrm{Ci}\end{array}$ \\
\hline 00115 & $06 / 17 / 71$ & ${ }^{244} \mathrm{Cm},{ }^{252} \mathrm{Cf}$ & $\begin{array}{l}{ }^{244} \mathrm{Cm} \\
{ }^{252} \mathrm{Cf}\end{array}$ & $\begin{array}{l}0.25 \mathrm{Ci} \\
0.17 \mathrm{Ci}\end{array}$ \\
\hline $\begin{array}{l}00125- \\
00126\end{array}$ & $06 / 30 / 71$ & ${ }^{244} \mathrm{Cm},{ }^{252} \mathrm{Cf}, \mathrm{F} . \mathrm{P}$. & $\begin{array}{l}{ }^{244} \mathrm{Cm} \\
{ }^{252} \mathrm{Cf}\end{array}$ & $\begin{array}{l}0.25 \mathrm{Ci} \\
0.17 \mathrm{Ci}\end{array}$ \\
\hline $\begin{array}{l}00413- \\
00414\end{array}$ & 03/09/72 & $\mathrm{Cm}, \mathrm{Cf}$ & $\begin{array}{l}{ }^{244} \mathrm{Cm} \\
{ }^{252} \mathrm{Cf}\end{array}$ & $\begin{array}{l}0.45 \mathrm{Ci} \\
0.22 \mathrm{Ci}\end{array}$ \\
\hline 00700 & $05 / 21 / 73$ & ${ }^{244} \mathrm{Cm}, \leq 0.25$ gram & ${ }^{244} \mathrm{Cm}$ & $0.36 \mathrm{Ci}$ \\
\hline 00844 & $03 / 29 / 74$ & ${ }^{244} \mathrm{Cm} \&{ }^{252} \mathrm{Cf},<1$ microgram & ${ }^{244} \mathrm{Cm}$ & $0.50 \mathrm{Ci}$ \\
\hline 00972 & $02 / 06 / 75$ & ${ }^{244} \mathrm{Cm},<1$ microgram & ${ }^{244} \mathrm{Cm}$ & $0.64 \mathrm{Ci}$ \\
\hline 01290 & $10 / 05 / 76$ & ${ }^{244} \mathrm{Cm} \&{ }^{252} \mathrm{Cf},<0.002 \mathrm{Ci}$ & $\begin{array}{l}{ }^{244} \mathrm{Cm} \\
{ }^{552} \mathrm{Cf}\end{array}$ & $\begin{array}{l}0.45 \mathrm{Ci} \\
0.11 \mathrm{Ci}\end{array}$ \\
\hline 01714 & $12 / 06 / 78$ & ${ }^{244} \mathrm{Cm}, 180 \mathrm{Ci} ;{ }^{252} \mathrm{Cf}, 0.1 \mathrm{Ci}$ & $\begin{array}{l}{ }^{244} \mathrm{Cm} \\
{ }^{252} \mathrm{Cf}\end{array}$ & $\begin{array}{l}0.12 \mathrm{Ci} \\
0.17 \mathrm{Ci}\end{array}$ \\
\hline
\end{tabular}


In 1996, extensive smear sampling of RH-TRU wastes from the hot cells in Building 7920 of the REDC confirmed that that the bulk of the alpha activity was contributed by ${ }^{244} \mathrm{Cm}$ and that, on average, only a few percent of the alpha activity was associated with isotopes meeting the TRU waste definition (Beauchamp et al. 1996). Limited sampling coupled with destructive assay (2 waste buckets from Building 7920 and one HEPA filter from Building 7930), however, indicated that ${ }^{244} \mathrm{Cm}$ and/or ${ }^{252} \mathrm{Cf}$ concentrations were $>10^{4} \mathrm{nCi} / \mathrm{g}$ and TRU waste concentrations were $>500$ $n C i / g$ ( R. E. Schreiber, Chemical Technology Division, personal communication, October 10, 1996; Nguyen 1997; Nguyen, Miller, and Downing 1997). Although sampling was not comprehensive enough to make a blanket declaration about the status of all REDC wastes with respect to the TRU waste definition, the initial results suggested that the bulk of the RH-wastes may well meet the criteria. (Bulky metal components such as equipment racks, which have a very large mass in relation to their contaminant loading, may prove to be an exception, but these wastes are generated infrequently and thus make up a small fraction of the waste inventory.)

Because of the greater diversity of the generating processes for CH-TRU wastes from the REDC (e.g., ranging from laboratory activities to hot cell operations) and the lack of sampling of these materials, it is not possible currently to predict what fraction of the CH-TRU inventory might meet the TRU waste definition. A more comprehensive sampling and destructive assay program, coupled with improved process knowledge and nondestructive assay technology (see, e.g., Meeks and Chapman 1997; Nguyen, Miller, and Downing 1997), is needed to attempt to fully address such questions and to confirm the results from the initial sampling of the RH-TRU waste components.

The examples just provided serve not only to illustrate the need for a reevaluation of past estimates of buried TRU wastes at ORNL but also indicate the difficulties faced by anyone attempting to reconstruct pre-1970 inventories from limited data and records covering disposals during 1970-1977. The need for enhanced waste characterization, e.g., to assist in resolving the issues raised in reviewing records and historical information associated with Tables 2 and 3 , is also highlighted.

\subsection{PURPOSE AND APPROACH}

It was determined that a review of the previous estimates of buried TRU wastes and reconciliation (to the extent possible) with current information was needed in order to attempt to reduce the overall level of confusion in extant estimates and to adopt a consistent set of information for use in future planning. The purpose of this review was therefore twofold: First, to attempt to explain both the rationale for and differences among the various estimates, and, second, to update the estimates based on the most recent information obtained from TRU waste characterization activities and from reviews of historical records. The latter included the TRU Waste Data Review which was conducted at ORNL in 1996: An expert panel's examination of and attempt to reconcile inconsistencies in data identified during preparation of the ORNL input for Revision 3 of the WIPP BIR. 


\section{REVIEW OF PAST ESTIMATES}

\subsection{BURIED SOLID TRU WASTES}

The wastes in question are a heterogeneous mix of materials from hot cell and glovebox operations at ORNL. Wastes include contaminated plastic materials, paper trash, cloth items (including protective clothing), metal (miscellaneous tools or equipment, piping, etc.), glass, filters (e.g., HEPA), and large bulky items such as equipment racks and glove boxes.

Materials disposed of in the 5-trench area in SWSA 5 South from 1970-1972 (Table 2) were primarily hot cell wastes from the REDC. These wastes are described in some detail in Appendix B. Wastes were often placed in individual containers (paint cans, plastic buckets, fiber drums, and 30- or 55-gal steel drums) before being placed into large concrete casks (Stewart et al. 1989; Arakawa et al. 1994). The 4-trench disposal area in SWSA 5 North was reserved for disposal of the bulkiest items. These were mainly gloveboxes but also included hoods, large equipment, and one calutron tank, which were placed inside large metal or plywood boxes prior to disposal (Stewart et al. 1989).

In aggregate, the volumetric proportions of major materials in the two post-1969 TRU waste disposal areas in SWSA 5 were approximately 10:5:2:2:1.5 for plastics, metal, paper, cloth, and glass, respectively (Stewart et al. 1989). In the absence of information on early waste characteristics, it is assumed that these rough proportions were maintained in TRU wastes disposed of prior to 1970. However, the use of large concrete casks as outer containers for RHTRU wastes originated with the start of operations at the REDC in 1966. Prior to that time, a wide variety of containers was used for disposal of TRU-contaminated materials.

\subsubsection{Volumetric Estimates}

A post-1969 ratio of solid TRU waste burials to total solid radioactive waste burials in Solid Waste Storage Area (SWSA) 5 at ORNL was used to generate the first volumetric estimates of buried TRU wastes (Appendix A; Lotts 1979; ORNL 1980; King 1981a, 1981b; Row 1983; King 1985). The ratio so derived (0.0373) was then multiplied by the estimated solid radioactive waste volume disposed of in SWSAs 3, 4, and $5\left(5.9\right.$ million $\mathrm{ft}^{3}$ or $\left.167,000 \mathrm{~m}^{3}\right)$ to obtain an estimate of the total volume of solid TRU wastes buried at ORNL $\left(220,000 \mathrm{ft}^{3}\right.$ or $\left.6230 \mathrm{~m}^{3}\right)$ (Table 4). No TRU waste burials have been recorded in SWSA 6, which became operational in 1973 .

The $6230-\mathrm{m}^{3}$ value obtained from this calculation has also been reported as the estimate of pre1970 TRU waste burials (Appendix A). However, other reference materials, including submittals for the DOE Integrated Data Base (IDB), indicate that the pre-1970 estimate was $5660 \mathrm{~m}^{3}$ (King 1981b) (Table 4), and that the $6230-\mathrm{m}^{3}$ value included the estimated value $p$ lus recorded values for TRU waste disposed of post-1969 (Lotts 1979; King 1982; Row 1983). 
Table 4. Estimates of buried waste inventories in Solid Waste Storage Areas 1-5 at ORNL made using back-extrapolations and accountability records ${ }^{\mathrm{a}}$

\begin{tabular}{|c|c|c|c|c|c|}
\hline \multirow[b]{2}{*}{ Solid Waste Storage Areas } & \multicolumn{2}{|c|}{ Volume $\left(10^{3} \mathrm{ft}^{3}\right)$} & \multicolumn{2}{|c|}{ Radioactivity $\left(10^{3} \mathrm{Ci}\right)$} & \multirow[b]{2}{*}{ Dates buried } \\
\hline & Total & TRU waste & Total $^{\mathrm{b}}$ & TRU & \\
\hline 1 and 2 & 100 & None & 6 & None & $1943-1946$ \\
\hline 3 & 700 & $26^{\mathrm{c}}$ & 47 & NA & $1946-1951$ \\
\hline 4 & 2000 & $75^{\mathrm{c}}$ & 105 & NA & $1951-1959$ \\
\hline \multirow[t]{2}{*}{5} & 3200 & $99^{c}$ & 221 & NA & $1959-1971^{d}$ \\
\hline & & $\begin{array}{c}20^{\mathrm{e}} \\
\left(569 \mathrm{~m}^{3}\right)\end{array}$ & & $\begin{array}{c}0.135^{\mathrm{f}} \\
(0.358 \mathrm{~kg})\end{array}$ & $1970-1977$ \\
\hline $\begin{array}{l}\text { Subtotal for Areas } \\
3,4 \text {, and } 5\end{array}$ & 5900 & $\begin{array}{c}200^{\mathrm{c}} \\
\left(5660 \mathrm{~m}^{3}\right)\end{array}$ & 373 & $\begin{array}{c}0.137^{f} \\
(5.2 \mathrm{~kg})\end{array}$ & $1946-1971^{d}$ \\
\hline $\begin{array}{l}\text { Subtotal for Areas } \\
3,4 \text {, and } 5\end{array}$ & 5900 & $\begin{array}{c}220 \\
\left(6230 \mathrm{~m}^{3}\right)\end{array}$ & 373 & $\begin{array}{r}0.272^{f} \\
(5.6 \mathrm{~kg})\end{array}$ & $1946-1977$ \\
\hline $\begin{array}{l}\text { Subtotal for Areas } \\
4 \text { and } 5 \text { only }\end{array}$ & 5200 & $\begin{array}{c}194 \\
\left(5440 \mathrm{~m}^{3}\right)\end{array}$ & 326 & $\begin{array}{c}0.272^{f} \\
(5.6 \mathrm{~kg})\end{array}$ & $1951-1977$ \\
\hline $\begin{array}{l}\text { Subtotal for Areas } \\
4 \text { and } 5 \text { if TRU content } \\
<100 \mathrm{nCi} / \mathrm{g} \text { in } 10 \% \text { of } \\
\text { buried volume }\end{array}$ & 5200 & $\begin{array}{c}175 \\
\left(4890 \mathrm{~m}^{3}\right)\end{array}$ & 326 & $\begin{array}{r}0.272^{\mathrm{f}} \\
(5.6 \mathrm{~kg})\end{array}$ & $1951-1977$ \\
\hline
\end{tabular}

${ }^{a}$ Sources: Appendix A; Bates (1983); Row (1983); Arakawa et al. (1994); King (1985). TRU $=$ transuranic; $N A=$ not available for individual areas (see text).

${ }^{b}$ Source: ORNL Solid Waste Information Management System; reported in Row (1982). Waste generators often provided only $\leq$ values. Thus, total activities may represent upper limits.

${ }^{\mathrm{C}}$ Based on back-extrapolations using ratio (0.0373) of volumes of TRU waste: total radioactive solid waste buried after 1969 . Uncertainty reportedly $\pm 50 \%$ (Appendix A).

${ }^{\mathrm{d}}$ Through June 30, 1971 [end of fiscal year (FY) 1971]. Waste burials other than for TRU 
waste ceased in 1973. No TRU wastes reported as having been buried in Solid Waste Storage Area 6, which succeeded Solid Waste Storage Area 5 and began operating in 1973.

'Source: ORNL Solid Waste Information Management System; see Arakawa et al. (1994). Recorded post-1969 burials included with pre-1970 estimate, yielding total of $119,000 \mathrm{ft}^{3}$, in Row (1982).

${ }^{\mathrm{f}}$ From accountability records for ${ }^{233} \mathrm{U}$ and ${ }^{239} \mathrm{Pu}$ before FY 1971 ; from records thereafter.

King (1981b) reported that the volume of solid TRU wastes buried irretrievably after 1969 totalled nearly $700 \mathrm{~m}^{3}: 450 \mathrm{~m}^{3}$ in boxes buried in Trenches $11,14,16$, and 17 in SWSA 5 North, and $246 \mathrm{~m}^{3}$ in concrete casks disposed of in SWSA 5 South. When these volumes are added to the pre-1970 estimate of about $5660 \mathrm{~m}^{3}$, the total increases to $6360 \mathrm{~m}^{3}$ (King 1981b). However, all references dated after 1981 (Appendix A; King 1982, 1985; Row 1983, 1984; including the IDB: ORNL 1984, 1985), cite the $6230-\mathrm{m}^{3}$ value (often rounded off to $6200 \mathrm{~m}^{3}$ ), as do several earlier sources (Lotts 1979; Appendix A).

The reason for this discrepancy appears to be that the post-1969 buried waste volume cited by King (1981b) was too high. Inventory estimates carried in the ORNL Solid Waste Information Management System (SWIMS) for the materials buried after 1969 totalled $569 \mathrm{~m}^{3}: 393 \mathrm{~m}^{3}$ in 63 containers (mainly boxes) located in SWSA 5 North, and $176 \mathrm{~m}^{3}$ in 107 containers in SWSA 5 South (Arakawa et al. 1994). When $569 \mathrm{~m}^{3}$ is added to the pre-1970 estimate of $5660 \mathrm{~m}^{3}$, the rounded total is 6230 (or 6200) $\mathrm{m}^{3}$ (Table 4).

A 6200- $\mathrm{m}^{3}$ value appears in the IDB from 1984 until 1992 (Rev. 8: ORNL 1992). In Rev. 8, the estimated volume of buried TRU waste at ORNL was reduced to $5947 \mathrm{~m}^{3}$ - for reasons unknown. One possibility is that the reduction was an attempt to account for materials containing $>10 \mathrm{nCi} / \mathrm{g}$ but $<100 \mathrm{nCi} / \mathrm{g}$ of TRU constituents (e.g., estimated as $10 \%$ of the total by King 1985). However, $6200 \mathrm{~m}^{3}$ minus $10 \%$ yields $5580 \mathrm{~m}^{3}$, not $5947 \mathrm{~m}^{3}$.

A recent exhaustive review of historical records, including classified information, on waste disposal at ORNL (H\&R 1997) indicates that it is unlikely that TRU waste was disposed of in SWSA 3, as formerly thought. Elimination of SWSA 3 would result in a reduction in the buriedTRU-waste estimate derived from back-extrapolation of about $12 \%$. Applying this percentage yields a volume of $5440 \mathrm{~m}^{3}$ (Table 4). Adjusting further for the percentage estimated by King (1985) to contain $>10 \mathrm{nCi} / \mathrm{g}$ but $<100 \mathrm{nCi} / \mathrm{g}$ of TRU radionuclides yields $4890 \mathrm{~m}^{3}$ (Table 4).

Given that the estimated error in the back-calculated, buried-TRU-waste volume was $\pm 50 \%$ (Appendix A), there is little point in quibbling about whether the estimate is $4890,5440,5580$, 6200,6230 , or $6360 \mathrm{~m}^{3}$. Under these conditions, use of more than one significant figure is not justified. (It is also likely that the potential error in the buried TRU waste volume estimate is 
much larger than $\pm 50 \%$; see Sect. 2.1.2)

After Rev. 8 of the IDB, estimates derived from back-extrapolations were no longer used, perhaps because of the uncertainties inherent in the technique and in the primary data used for calculations (see, e.g., Trabalka 1987). Beginning with Rev. 9, only recorded data for post-1969 burials were reported in the IDB.

In Rev. 9 of the IDB, however, a pre-1976 buried waste volume of $1185 \mathrm{~m}^{3}$ was given. This volume includes a $475-\mathrm{m}^{3}$ liquid LLW-grout injection at the Old Hydrofracture Facility in 1972 (see discussion on radioactivity estimates in buried wastes and on hydrofracturing contributions in Sects. 2.1.2 and 2.3.2, respectively). When the hydrofracturing volume is subtracted from the total, the remainder is $710 \mathrm{~m}^{3}$. However, the author is unable to relate this remainder to any recorded or published value. Based on the radionuclide inventory reported in ORNL's IDB submittal for Rev. 9 (ORNL 1994a; see following section), the volume should have been given as $176 \mathrm{~m}^{3}$ (for 107 containers, primarily concrete casks, buried in SWSA 5 South; see above). [At the time that Rev. 9 of the IDB was published, the $393 \mathrm{~m}^{3}$ of wastes buried in Trenches 11, 14, 16, and 17 in SWSA 5 North (Table 2; Fig. 2) were considered stored (Stewart et al. 1989). Otherwise, the total would have been $569 \mathrm{~m}^{3}$, as given in Table 4.] The $176-\mathrm{m}^{3}$ value was reported as the buried-TRU-waste volume estimate in Revs. 10, 11, and 12 of the IDB (ORNL 1994b, 1995, 1996).

The numbers and types of containers and the internal volumes of 4 "-thick-walled casks buried in 5 trenches in SWSA 5 South were adjusted by the author based on the findings from the 1996 TRU Waste Data Review at ORNL, and from his own review. The most substantive changes included: (1) deletion of one waste box and one concrete cask, and addition of another cask (see Sect. 1.1.2), (2) reduction of the internal volume of 4-in-thick-walled concrete casks from $65.7 \mathrm{ft}^{3}$ to $58.5 \mathrm{ft}^{3}$, and (3) replacement of "dummy" values of $100 \mathrm{ft}^{3}$, that had been used for the internal volumes of sixteen 4-in- or 6-in-thick-walled casks, with the corrected value of $58.5 \mathrm{ft}^{3}$. As a result, the number of containers was reduced from 107 to 106 , the mix of containers was changed slightly [from 105 casks, one box, and one 55-gal drum in the most recent compilation by Arakawa et al. (1994) to 105 casks and one 55-gal drum], and the volume was reduced from 176 $\mathrm{m}^{3}$ to $169 \mathrm{~m}^{3}$ (see Table 5 in Sect. 2.1.2).

The volume of wastes buried in Trenches 11,14,16, and 17 in SWSA 5 North was increased from $393 \mathrm{~m}^{3}$ to $403 \mathrm{~m}^{3}$ (Table 5 in Sect. 2.1.2), as a result of information developed during the current review. This resulted when missing volumes for 2 containers were added: 3 containers of equal size from the same facility were transferred on the same date, but the volumes for two of the containers were apparently dropped inadvertently and recorded as zero during transcription into the data base.

Another finding from the current review is that a set of six 55-gal drums, included as buried wastes in the response to the DOE Carlsbad Area Office as part of Rev. 3 to the Baseline Inventory Report for the WIPP (Monk 1996), have also apparently been misclassified. These 
containers were listed as buried because they couldn't be located in storage areas. However, three were received in the 1980s, well after the last TRU waste burials at ORNL; none match the profile of either drums or boxes buried earlier; and none had identified disposal locations.

Records for several of the drums indicate that they were examined in the Waste Examination and Assay Facility at ORNL and returned to the waste generators because they contained items noncompliant with waste acceptance criteria. It is likely that all may have been returned to waste generators for similar reasons. It is recommended that all six drums be removed from the buried waste inventory until conclusive documentation of burial is produced.

\subsubsection{Radionuclide Content}

An early estimate of $13 \mathrm{~kg}$ of TRU radionuclides buried at ORNL appears in a 1976 ERDA Report (76-43, Vol. 4). However, the source of the estimate was not provided, and no estimate for the associated volume of buried TRU waste was given.

Accountability records were used initially to estimate the mass and activity of buried TRU wastes (Appendix A; King 1982; Row 1983) for submittals to the Integrated Data Base and its predecessors (e.g., ORNL 1980, 1984, 1985). The initial estimate included $3.5 \mathrm{~kg}$ of ${ }^{233} \mathrm{U}$ (which was then being managed as a "transuranic" isotope at the instruction of the DOE-Oak Ridge Operations Office) and $1.7 \mathrm{~kg}$ of ${ }^{239} \mathrm{Pu}$, totalling $5.2 \mathrm{~kg}$ (Table 4).

The initial estimate was increased at the end of calendar year 1982 to $5.6 \mathrm{~kg}$ (272 Ci) by the addition of $358 \mathrm{~g}$ and $135 \mathrm{Ci}$, respectively (Table 4; Row 1983; Trabalka 1987). Although neither the basis for the revision nor the isotopic content were documented, it seems likely that the addition represented the alpha activity--including that of ${ }^{244} \mathrm{Cm}$ and ${ }^{252} \mathrm{Cf}$--in the burials recorded after 1969. It appears that this was simply an oversight in the original estimates. The 272-Ci value was often rounded off to $270 \mathrm{Ci}$ in the IDB (e.g., in Revs. 6 and 7: ORNL 1991, 1992).

One could speculate that the estimate might have been revised to incorporate contributions from projected ingrowth of daughter products. However, the fact that both the mass and radioactivity were increased suggests otherwise, i.e., that the increase reflected an addition to the buried inventory that had not been included in the original estimate. In addition, a footnote to Table 3.2 in Rev. 6 of the IDB (ORNL 1991) indicates that the 270-Ci value represents the total radioactivity excluding contributions from daughter products and beta or gamma emitters. Further, the total recorded alpha activity in the $569 \mathrm{~m}^{3}$ of wastes buried in SWSA 5 after 1969 (see preceding section) was reportedly $127 \mathrm{Ci}$ (Arakawa et al. 1994; ORNL SWIMS TRU Database), a value that is very close to the $135-\mathrm{Ci}$ addition to the buried waste inventory particularly when one takes into account how the waste inventory data have been manipulated (Sect. 1.1.2). (E. M. King was asked about this issue in a post-retirement interview in 1987, but was unable to shed any further light on the subject.)

Correcting the inventory to account for the elimination of SWSA 3 as a TRU waste disposal site 
and for the fraction of alpha-contaminated buried waste containing $<100 \mathrm{nC} / \mathrm{g}$ TRU constituents would likely not affect the estimated TRU radionuclide content even though waste volumes are slightly reduced (Table 4). Accountability records do not indicate that disposals of significant quantities of ${ }^{233} \mathrm{U}$ and ${ }^{239} \mathrm{Pu}$ took place prior to 1958 (e.g., H\&R 1997) and records for post-1969 disposals (Stewart et al. 1989; ORNL Waste Tracking System Data Base) indicate that the bulk of the inventory is contained in a relatively small fraction of the containers, all of which should have been disposed of in SWSAs 4 and 5 .

If the experience with the ORNL Gunite tanks is any indicator, accountability records are probably an inadequate tool for estimating quantities of radionuclides in wastes. Transuranic radionuclide inventories obtained from analyses of homogenized sludge samples were 5 times greater than those based on accountability records (Weeren, Lasher, and McDaniel 1985; ORNL 1987). Internal inconsistencies in information contained in accountability records pertaining to solid wastes sent to SWSA 5 have also recently been described by H\&R (1997).

Based on analyses of individual isotopes in ORNL waste storage tank sludges (including those in the Gunite tanks), the TRU content in pre-1970 buried wastes, which was based on ${ }^{233} \mathrm{U}$ and ${ }^{239} \mathrm{Pu}$ alone, is probably low, perhaps by an additional factor of 2 to 5 , because isotopes such as ${ }^{238} \mathrm{Pu}$ and ${ }^{241} \mathrm{Am}$ were not included (See Appendix in ORNL 1987; also Keller et al. 1996a,b). Recent efforts to characterize ORNL TRU wastes indicate the presence of many other isotopes, further reinforcing the notion that buried waste inventories may have been underestimated. Underreporting of all TRU isotopes is indicated in the composition of post-1969 buried and stored TRU wastes (Table 2; Sect. 1.1.2).

In toto, the experience with characterization of tank sludges and reporting of post-1969 TRU waste composition suggests that the TRU inventory in buried waste may have been underestimated by an order of magnitude (or more). The potential for order-of-magnitude (or more) errors in the volume estimates also cannot be excluded given the nature of the backextrapolation technique used and the uncertainties in ORNL's limited waste records.

The revised 270-Ci and 5.6-kg estimates appear in the IDB until Rev. 8 (ORNL 1992). In Rev. 8, the mass and activity of TRU isotopes in buried TRU wastes at ORNL are given as unknown. In Rev. 9 of the IDB, the pre-1976 estimate of total radioactivity is given as $24,900 \mathrm{Ci}$ and $25 \mathrm{Ci}$ of long-lived TRU radionuclides (ORNL 1994a). However, the estimate of total radioactivity includes data for a $475-\mathrm{m}^{3}$ liquid LLW-grout injection at the Old Hydrofracture Facility in 1972 (see discussion in preceding section and in Sect. 2.3.2).

When the hydrofracturing values are subtracted from the total, the remainder in buried solid waste becomes $243 \mathrm{Ci}$ total with $25 \mathrm{Ci}$ of long-lived TRU radionuclides. These last two values are consistent with the estimates of total radioactivity and of Pu-Am activity previously reported for wastes buried in SWSA 5 South during 1970-1972 (Arakawa et al. 1994; ORNL SWIMS TRU Data Base). The total activity estimate of $243 \mathrm{Ci}$ total is repeated in Revs. 10,11, and 12 of the IDB (ORNL 1994b, 1995, 1996). However, in each of these reports, the activity of the TRU 
radionuclides was reported as $100 \mathrm{Ci}$ because ${ }^{244} \mathrm{Cm}$ activity was included. The actual total (including $27 \mathrm{Ci}$ of ${ }^{244} \mathrm{Cm}$, but excluding data for ${ }^{252} \mathrm{Cf}$ ) was $52 \mathrm{Ci}$ of TRU isotopes, which was then rounded up to $100 \mathrm{Ci}$ (ORNL 1994b; ORNL SWIMS TRU Data Base).

The isotopic content (and volume, as described in Sect. 2.1.1) of the materials disposed of in the 4- trench area in SWSA 5 North (Table 2; Fig. 2) and in 5 trenches in SWSA 5 South after 1969 have been adjusted (Table 5), based on the findings from both the 1996 TRU Waste Data Review at ORNL and the current review, and also as a result of revisions to conversion factors for specific activities for some radionuclides (e.g., ${ }^{137} \mathrm{Cs}$ ), which were apparently made when the ORNL data were transferred from the SWIMS to the ORNL Waste Tracking System Data Base.

Because of offsetting (small) errors, the total radioactivity (243 Ci) in the 5 trenches in SWSA 5 South remains the same (Table 5). The largest change in the inventory for an individual radionuclide is that for ${ }^{241} \mathrm{Am}$, but this still only represents an increase of $5 \%$. The changes in radionuclide inventories and volumes (given in Sect. 2.1.1) are relatively small in absolute terms, and thus would not significantly affect conclusions derived from previous use of the data (e.g., in baseline risk assessments for remediation). Such uses are already limited by the lack of formal waste characterization as described in Sect. 1.1.2.

Table 5 also includes revised inventories for the 63 containers irretrievably buried in SWSA 5 North that had previously been misclassified as stored wastes. The principal changes involved correcting errors made in translating radionuclide data from original disposal forms into the ORNL Waste Tracking System for two containers (ATN Nos. 816 and 859). In addition, revisions to conversion factors for specific activities for some radionuclides (e.g., $\left.{ }^{241} \mathrm{Am}\right)$ resulted in very small changes for several containers. The net result was a $10 \%$ decrease in the inventory of ${ }^{244} \mathrm{Cm}$ and a $50 \%$ increase in that of ${ }^{241} \mathrm{Am}$. The total radioactivity was only slightly affected, decreasing about $4 \%$, and the net volume was increased $2.5 \%$, from $393 \mathrm{~m}^{3}$ to $403 \mathrm{~m}^{3}$ (Table 5).

It probably cannot be stressed enough that uncertainties in the values in Table 5 are very large. Reporting of radionuclides was typically incomplete - and, in some cases, completely absent notably for wastes in concrete casks. The values reported typically were only crude estimates. And the implications of the lack of correspondence between data base records and original input by waste generators for the RH-TRU waste casks were discussed earlier in Sect. 1.1.2.

The limited information from recent attempts to characterize RH-TRU wastes from the REDC (Sect. 1.1.2) indicates that the RH-wastes buried in the 5 trenches in SWSA 5 South are suspect TRU wastes. It is probably prudent to make the assumption that these are TRU wastes for purposes of remediation planning, at least until we have more comprehensive information from additional characterization of newly generated RH-TRU wastes from the REDC.

Assuming that the reported isotopic content for containers in the 4-trench area in SWSA 5 North was accurate, one can attempt to estimate the TRU concentrations in individual containers from either the reported TRU content or calculations [e.g, by assuming that a few $(\leq 5)$ percent on 
Table 5. Recorded radioactivity in and internal volume of solid TRU waste containers buried in Solid Waste Storage Area (SWSA) 5 at ORNL, updated from recent data evaluation activities ${ }^{2}$

105 casks and 155 -gal drum buried in 197.0-1972 in 5 trenches in SWSA 5 South $^{\mathrm{b}}$
62 boxes and 1 Calutron tank buried in 1975-1977 in 4 trenches in SWSA 5 North $^{\mathrm{c}}$
Radionuclide $^{d}$

\begin{tabular}{|c|c|c|}
\hline${ }^{131} I$ & $5.00 \times 10^{-1}$ & e \\
\hline${ }^{137} \mathrm{Cs}$ & $8.69 \times 10^{1}$ & -.--_..._-_-_- \\
\hline${ }^{233} \mathrm{U}$ & -.---.--.--- & $1.06 \times 10^{-3}$ \\
\hline${ }^{235} \mathrm{U}$ & $2.68 \times 10^{-4}$ & $2.37 \times 10^{-7}$ \\
\hline${ }^{237} \mathrm{~Np}$ & ----.-_._---- & $1.40 \times 10^{-8}$ \\
\hline${ }^{238} \mathrm{Pu}$ & -.--.--...... & $1.71 \times 10^{-4}$ \\
\hline${ }^{239} \mathrm{Pu}^{\mathrm{f}}$ & $1.85 \times 10^{1}$ & 4.32 \\
\hline${ }^{240} \mathrm{Pu}^{\mathrm{f}}$ & - & $2.27 \times 10^{-1}$ \\
\hline${ }^{241} \mathrm{Pu}$ & 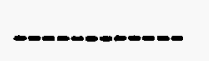 & $3.09 \times 10^{-3}$ \\
\hline${ }^{241} \mathrm{Am}$ & 6.84 & 1.03 \\
\hline${ }^{243} \mathrm{Am}$ & $1.99 \times 10^{-6}$ & $2.00 \times 10^{-2}$ \\
\hline${ }^{244} \mathrm{Cm}$ & $2.72 \times 10^{1}$ & $5.88 \times 10^{1}$ \\
\hline${ }^{252} \mathrm{Cf}$ & 7.18 & $9.58 \times 10^{-3}$ \\
\hline Unidentified & $2.60 \times 10^{1}$ & $1.26 \times 10^{2}$ \\
\hline Totals & $2.43 \times 10^{2}$ & $1.90 \times 10^{2}$ \\
\hline Total volume & $169 \mathrm{~m}^{3}$ & $403 \mathrm{~m}^{3}$ \\
\hline
\end{tabular}

${ }^{\text {a }}$ Source: ORNL Waste Tracking System database (June 13, 1997), amended as noted in text. There is little correspondence between data base records and original inputs by waste generators for wastes in concrete casks (Sect. 1.1.2).

${ }^{\mathrm{b}}$ Trench numbers: T0128, T0168, T0188, T0206, and T0214.

'Trench numbers: TT011, TT014, TT016, TT017.

${ }^{\mathrm{d}}$ Reporting of radionuclides was incomplete. Data typically are crude estimates.

${ }^{\mathrm{e}}$ Data not provided.

${ }^{i}$ Values for ${ }^{239} \mathrm{Pu}$ generally include ${ }^{240} \mathrm{Pu} ;{ }^{240} \mathrm{Pu}$ values reported for only a few containers. 
average of the activity in containers for which only ${ }^{244} \mathrm{Cm}$ and/or ${ }^{252} \mathrm{Cf}$ are reported is made up of long-lived TRU isotopes; Sect. 1.1.2]. Because materials disposed of at this site were mostly gloveboxes, an order of magnitude increase in concentrations is included in volume-density calculations to account for voids. This approach is conservative and thus tends to overestimate the TRU concentrations in the containers. The results of this exercise suggest that about $1 / 4$ of the containers disposed of in the SWSA 5 North may have wastes meeting the current TRU waste definition. The remainder appear to contain mainly LLW while the status of a small fraction is indeterminate.

This seemingly simple but still rather convoluted exercise serves to illustrate how difficult it is to use existing data for post-1969 disposals to determine their waste classification, let alone to serve as a basis for performing back-extrapolations to generate a profile of pre-1970 buried TRU wastes. The exercise also indicates that the fraction of the volume of waste buried after 1969 that is TRU waste is highly uncertain, not even accounting for uncertainties in actual volumes vs internal container volumes. The fraction that is not TRU waste could thus exceed $50 \%$ of the recorded internal volume $\left(0.75 \times 403 \mathrm{~m}^{3}\right) /\left(169 \mathrm{~m}^{3}+403 \mathrm{~m}^{3}\right)$ even if all of the materials in the concrete casks buried in SWSA 5 South are eventually classified as TRU wastes.

Waste volumes given in Table 5 are maximum values: Total internal volumes of containers used in default of actual waste volume estimates. The latter are available but have large uncertainties because of the presence of voids. Voids are both internal and external to waste packages. Internal voids occur between or inside individual waste items while external voids are present between the individual packages and the outer container: Box, cask, or drum. Internal voids are dependent both on the types of materials within packages, and the fraction of the useable package volume occupied by wastes. Methods for estimating voids external to waste packages were described by Stewart et al. (1989).

\subsubsection{Hazardous Waste Content}

The bulk of the stored containers are either known or suspect RCRA mixed wastes (Arakawa et al. 1994): "Known" because records indicated the presence of lead or other hazardous materials, or "suspect" either because records indicated the potential presence of hazardous materials (typically lead) or because insufficient information was available to make a determination. Appendix E in Stewart et al. (1989) provides detailed information on the reported hazardous chemical constituents in wastes from the two post-1969 disposal areas in SWSA 5. In the absence of information on earlier waste characteristics, it is assumed that similar materials were included in TRU wastes disposed of prior to 1970. 


\subsection{TRU-CONTAMINATED SOILS PROXIMATE TO BURIED SOLID TRU WASTES}

Leaching of buried solid wastes can produce concentrations of long-lived TRU radionuclides in the surrounding soils $>100 \mathrm{nCi} / \mathrm{g}$. Hence, the need exists for estimates of TRU inventories in contaminated soils to support remedial action planning.

\subsubsection{Volumes}

The total volume of TRU-contaminated soils resulting from solid waste burials was estimated to range from a low value equal to twice the volume of buried TRU waste (Appendix A; Row 1983, 1984; ORNL 1991) to a high value equal to 10 times the total volume of all solid radioactive waste disposed of at ORNL (ORNL 1981; Row 1983, 1984; ORNL 1991). The high estimate $\left(1,600,000 \mathrm{~m}^{3}\right)$ was originally intended to indicate the quantity of material that might have to be excavated to recover all TRU waste and soil contaminated with $>100 \mathrm{nCi} / \mathrm{g}$ of TRU-waste constituents. The high estimate was later lowered to ten times the volume of buried solid TRU wastes $\left(60,000 \mathrm{~m}^{3}\right)$ to provide an upper limit for the contaminated soil volume resulting from the burial of TRU waste only (Row 1983, 1984).

However, the original high estimate of $1,600,000 \mathrm{~m}^{3}$ was made with the knowledge that TRU wastes were buried in the solid waste disposal areas used for LLW prior to 1971. "In some cases, the alpha[-emitting] wastes were put in separate trenches and covered with concrete but this was not practiced consistently" (King 1981b). Maps indicate that approximately $1 / 3$ to $1 / 2$ of the disposal areas in the principal SW'SAs (4 and 5) were used for trench burial of alpha wastes prior to 1971 (Webster 1976; Bates 1983; Coobs and Gissel 1986). Reports on early waste disposal practices at ORNL indicate that concrete was typically used to cap alpha-emitting-waste trenches in SWSA 4, which was operational during 1951-1959.

The practice of segregating and capping the alpha-contaminated wastes was reportedly discontinued between 1958 and 1970 during the operational life of SWSA 5 South (Webster 1976). However, field surveys in SWSA-4 burial areas that were mapped as containing alphacontaminated wastes in concrete-covered trenches located very few trenches that were actually concrete capped (Trabalka 1987). And during 1970-1972 in SWSA 5 South and 1975-1977 in SWSA 5 North, TRU wastes are known to have been buried in trenches backfilled with concrete (Stewart et al. 1989). Thus, it is difficult to judge how well the locations of buried TRU wastes can be determined using historical information and records.

The TRU-contaminated soil volume for ORNL was later reported as unknown in Revs. 8 through 11 of the IDB (ORNL 1992, 1994a, 1994b, 1995). These revisions of the IDB included a TRUcontaminated soil volume estimaie for only one DOE site. No information on TRUcontaminated soils for any DOE site was included in Rev. 12 of the IDB (ORNL 1996). 


\subsubsection{Radionuclide and Hazardous Waste Content}

No separate estimates exist for the inventories of radionuclides or hazardous constituents in contaminated soils. These inventories are unknown fractions of the original waste contents, which are themselves highly uncertain.

\subsection{TRU-CONTAMINATED SOILS/WASTE MATRICES RESULTING FROM LIQUID WASTE DISPOSAL}

\subsubsection{Liquid Waste Seepage Pits and Trenches}

An additional $1000 \mathrm{~m}^{3}$ of contaminated soil and sludge containing $0.3 \mathrm{~kg}(8 \mathrm{Ci})$ of ${ }^{233} \mathrm{U}$ and ${ }^{239} \mathrm{Pu}$ was estimated by King (1981a) to have resulted from liquid waste disposal operations at ORNL. The ${ }^{233} \mathrm{U}$ and ${ }^{239} \mathrm{Pu}$ content was derived initially by assuming that soil concentrations associated with the LLW Seepage Pits and Trenches were comparable to overall concentrations in the solid waste disposal areas [i.e., $\left(5.2 \mathrm{~kg} / 18,000 \mathrm{~m}^{3}\right) \times 1000 \mathrm{~m}^{3}=0.3 \mathrm{~kg}$ (Appendix A)]. The "solid waste contaminated subsurface soil volume" used in the calculation was the estimate of the buried solid TRU waste volume plus twice that same value to account for proximate contaminated soil, i.e., the "minimum" volume estimate described in Sect. 2.2.1.

The $1000-\mathrm{m}^{3}$ estimate for the soil-sludge volume contaminated to $>100 \mathrm{nCi} / \mathrm{g}$ with long-lived TRU radionuclides appears to represent a conservative upper limit, but the estimates of radionuclide content appear to be of little value and are inconsistent with other information. The estimated sludge volume in Trench 7, for example, was $12 \mathrm{~m}^{3}$ (Trabalka 1987), derived from inventory and concentration data for ${ }^{90} \mathrm{Sr}$ reported by Olsen et al. (1982). If we assume that the TRU waste inventories of the 7 Pits and Trenches are proportional to either the waste volume or the mass of Pu discharged (Table 6), then the estimated TRU waste volume is about 5 times that in Trench 7 or about $60 \mathrm{~m}^{3}$. Because of the limited sampling of Trench-7 sludges and the uncertainty inherent in using wasce volumes (or contaminant discharges) to perform such estimates, one cannot exclude the possibility that the inventory of TRU wastes in the Pits and Trenches is an order of magnitude larger. Further sampling of the residuals in the LLW Seepage Pits and Trenches will be needed to provide a valid estimate.

About $600 \mathrm{~g}$ (about $50 \mathrm{Ci}$ ) of ${ }^{239} \mathrm{Pu}$ alone was reportedly disposed of in the Pits and Trenches (Table 6; Lotts 1979; ORNL 1986; Trabalka 1987). Sampling of sludge in Trench 7 indicates that other TRU isotopes $\left({ }^{238} \mathrm{Pu},{ }^{241} \mathrm{Am}\right.$ ) and ${ }^{233} \mathrm{U}$ are also present in significant concentrations (Olsen et al. 1983). Comparable data are not available for Pits 2, 3, and 4, and Trench 5, which, along with Trench 7 , received $>99.9 \%$ of the radionuclide inventory (including about $800,000 \mathrm{Ci}$ of ${ }^{90} \mathrm{Sr}$ and ${ }^{137} \mathrm{Cs}$ ) disposed of via liquid waste seepage at ORNL (Table 6; ORNL 1986; Spalding 1987; Trabalka 1987).

Unfortunately, the actinide data obtained from sampling the sludge in Trench 7 are problematic, 
Table 6. Radioactivity and volume of liquid low-level wastes discharged to the Seepage Pits and Trenches at ORNL

\section{Radionuclides}

${ }^{239} \mathrm{Pu}^{\mathrm{a}, \mathrm{b}} \quad$ Fission and activation products $(\mathrm{Ci})^{\mathrm{c}}$

\begin{tabular}{|c|c|c|c|c|c|c|c|}
\hline Site & Service dates & Volume $\left(\mathrm{m}^{3}\right)$ & (Ci) & (g) & ${ }^{137} \mathrm{Cs}$ & ${ }^{90} \mathrm{Sr}$ & Total \\
\hline Pit 1 & $1951^{d}$ & $4.5 \times 10^{1}$ & $2.3 \times 10^{-2}$ & $2.66 \times 10^{-1}$ & $2.33 \times 10^{2}$ & Not reported & $3.89 \times 10^{2}$ \\
\hline Pits $2-4^{\mathrm{e}}$ & $1952-1962^{d}$ & $9.1 \times 10^{4}$ & $3.1 \times 10^{1}$ & $3.64 \times 10^{2}$ & $1.84 \times 10^{5}$ & $4.20 \times 10^{4}$ & $5.22 \times 10^{5}$ \\
\hline Trench 5 & $1960-1966$ & $3.6 \times 10^{4}$ & $1.1 \times 10^{1}$ & $1.32 \times 10^{2}$ & $2.06 \times 10^{5}$ & $\leq 9.70 \times 10^{4}$ & $3.10 \times 10^{5}$ \\
\hline Trench 6 & 1961 & $4.9 \times 10^{2}$ & $1.4 \times 10^{-1}$ & 1.63 & $6.65 \times 10^{2}$ & $1.45 \times 10^{2}$ & $1.34 \times 10^{3}$ \\
\hline Trench 7 & $1962-1966$ & $3.2 \times 10^{4}$ & $1.1 \times 10^{1}$ & $1.27 \times 10^{2}$ & $2.31 \times 10^{5}$ & $4.83 \times 10^{4}$ & $2.84 \times 10^{5}$ \\
\hline
\end{tabular}

${ }^{a}$ Source: ORNL (1986), except where noted.

${ }^{\mathrm{b}}$ Includes ${ }^{240} \mathrm{Pu}$; activity calculated from measurements of $\mathrm{Pu}$ mass given, using the adjusted isotopic distribution (atom \%) for Trench 7 sludges in footnote to Table 3 of Olsen et al. (1983): $83.4 \%\left({ }^{239} \mathrm{Pu}\right) ; 14.1 \%\left({ }^{240} \mathrm{Pu}\right)$; other isotopes $(2.5 \%)$.

'Source: Spalding (1987).

${ }^{d}$ Sites were used for other purposes after these dates, e.g., for disposal of process waste sludges in Pits 2-4.

${ }^{e}$ Because of the mode of operation, it is not possible to apportion the radioactivity among the three Pits, although Lomenick et al. (1967) estimated on the basis of core sampling that Pits 2 and 3 contain all of the ${ }^{90} \mathrm{Sr}$ and $85 \%$ of the ${ }^{137} \mathrm{Cs}$ discharged. Individual isotopes were not determined prior to 1960 ; values for ${ }^{137} \mathrm{Cs}$ and ${ }^{90} \mathrm{Sr}$ are based on estimates of Lomenick et al. (1967). 
and cannot be used to estimate the total TRU content of the other sites. Mass spectrometric data for plutonium indicated that $>80$ atom $\%$ was ${ }^{241} \mathrm{Pu}$ :

"The abundance values for ${ }^{241} \mathrm{Pu}$ are unexpectedly [anomalously] high. No production method or decay scheme of reactor-produced nuclides that would yield plutonium of this composition has been identified. It is thought to be unlikely that a sufficient quantity of ${ }^{241} \mathrm{Pu}$ has been separated to cause such high values . . . The isobaric similarity of results for sections $\mathrm{A}$ and $\mathrm{B}$ preclude a sampling anomaly. Isobaric interference from ${ }^{241} \mathrm{Am}$ is not believed to be responsible for the results . . Until more sampling can be completed the results are reported as the best determinations available" (Olsen et al. 1983).

This author has not seen atom $\%$ values for ${ }^{241} \mathrm{Pu}$ in excess of $20 \%$ in records for waste materials from ORNL. In those cases where ${ }^{241} \mathrm{Pu}$ content was unusually high, the atom $\%$ values for ${ }^{242} \mathrm{Pu}$ and ${ }^{241} \mathrm{Pu}$ were both elevated. However, in the Trench 7 samples, the reported atom $\%$ for ${ }^{242} \mathrm{Pu}$ was $<0.5 \%$ (Olsen et al. 1983).

Plutonium-241 enrichment was performed in the ORNL calutrons. However, the quantities produced were relatively small (J. G. Tracy, Chemical Technology Division, ORNL, personal communication, July 14,1997 )--and certainly less than the $\geq 20,000 \mathrm{Ci}$ inventory that sampling and analysis by Olsen et al. (1983) indicated for Trench 7.

The author thinks that mass spectrometric data for Pu were "scrambled"somehow in the output. The data look very much like those from analyses of sludges from ORNL waste storage tanks (Keller $1996 \mathrm{a}, \mathrm{b}$ ) if the value reported for ${ }^{241} \mathrm{Pu}$ is actually the ${ }^{239} \mathrm{Pu}$ value and the value reported for ${ }^{239} \mathrm{Pu}$ is actually the ${ }^{240} \mathrm{Pu}$ value. Unfortunately, there is no way to confirm or deny this hypothesis without further sampling of the residuals in the Seepage Pits and Trenches.

The sludge sampling results also indicated the presence of $430 \mathrm{Ci}$ of ${ }^{241} \mathrm{Am}$ in Trench 7. Although this value also was unexpectedly high, there exists a potential explanation for its presence. Much of the ${ }^{241} \mathrm{Am}$ could conceivably have been a waste product from a ${ }^{242} \mathrm{Cm}$ production program conducted at ORNL in 1963-1964 (Jolley et al. 1994), during the time that Trench 7 was operational. An argument against this hypothesis is that the quantity of ${ }^{241} \mathrm{Am}$ involved (125 g) seems rather large. It is questionable whether efforts to recover quantities of ${ }^{241} \mathrm{Am}$ of this magnitude would not have been inherent in the process. Confirmation of the high ${ }^{241} \mathrm{Am}$ content observed in the sludges from Trench 7 will likewise require further sampling.

In Rev. 8 of the IDB (ORNL 1992), the estimate of the TRU-contaminated soil volume associated with liquid waste disposal was temporarily reduced from $1000 \mathrm{~m}^{3}$ to $510 \mathrm{~m}^{3}$ (for reasons unknown), and then was increased back to $1000 \mathrm{~m}^{3}$ in Rev. 9 (ORNL 1994a). In both Revs. 8 and 9, the mass and isotopic composition of the contaminants are given as unknown. In Revs. 10,11, and 12 of the DB (ORNL 1994b, 1995, 1996), the volume as well as the mass and isotopic composition of the contaminants are reported as unknown. 
Although measurements of hazardous chemical concentrations in liquid LLW discharged to the Seepage Pits and Trenches were not performed (ORNL 1986; Spalding 1987), the characteristics of the most highly contaminated soil/sludge residues should be fairly similar to those of the sludges in the Melton Valley Storage Tanks (MVSTs) at ORNL (e.g., Keller 1996b). This should also be the case for beryllium originating from the Y-12 Plant. Water contaminated with Be was reportedly hauled from the Y-12 Plant to the "X-10 Burial Pit" in a 1500-gal tank mounted on a truck starting in April 1959 (Y-12 Plant 1984). After the Seepage Pits and Trenches were taken out of service, the Be-contaminated water was reportedly discharged into the ORNL Liquid-LLW System at the [South] Tank Farm access point until September 1983 (Y-12 Plant 1984).

All of the MVST sludges exceed the total metal limits (20 times the EPA Toxicity Characteristic Leaching Procedure extraction limits) for lead and mercury, and sludges from two tanks are over or near the limit for chromium. Most radioactive waste sludge samples from ORNL have exceeded the total metal limits for these three metals (Keller 1996a,b).

\subsubsection{Subsurface Grout Sheets Produced by the New Hydrofracture Facility}

The ORNL initiated the use of the hydrofracturing process to dispose of liquid-LLW supernatants from the Gunite waste storage tanks in 1966 . These operations were conducted at the Old Hydrofracture Facility (OHF), which is located adjacent to SWSA 5, until 1979. During 1982 to 1984, TRU waste sludges (along with some liquid LLW) from the Gunite tanks were disposed of via the New Hydrofracture Facility (NHF), which is located southwest of the OHF and on the opposite side of a small stream called Melton Branch (Fig. 1).

Subsurface grout sheets were produced by injecting a waste-grout slurry between layers of shale to a depth of approximately $300 \mathrm{~m}$ below the surface. It was originally thought that the low permeability of the shale, the depth of the injection zone, and the integrity and sorptive properties of the grout (cement-fly ash-clay mixture) would serve to limit migration of contaminants, thus representing a form of greater-confinement-disposal (NAS 1985). However, records indicated that a number of injections at the NHF may have had an unacceptably low grout content and ${ }^{90} \mathrm{Sr}$ has been observed at concentrations of several microCi $/ \mathrm{L}$ in deep-monitoring wells located near the periphery of the grout sheets. The NHF grout sheets are now considered remedial action sites (ORNL 1987a; Trabalka 1987).

\subsubsection{Volumes and Contaminant Content}

Estimates of the volume $\left(9430 \mathrm{~m}^{3}\right)$ and radionuclide inventories (totalling $680,000 \mathrm{Ci} ; 2100 \mathrm{Ci}$ of long-lived TRU isotopes) in TRU waste-grout mixtures were included as part of the buried solid waste inventory in Rev. 9 of the Integrated Data Base (IDB) in 1992 (Tables 3.8-3.12 in ORNL 1994a). Most of these values were deleted from the IDB in the following year. Footnotes indicating the changes were included in two tables in Rev. 10 of the IDB (ORNL 1994b), but the 
decayed radioactivity was retained. Tables 3.11 (Rev. 10; ORNL 1994b), 3.15 (Rev. 11; ORNL 1995), and 3.21 (Rev. 12; ORNL 1996), respectively, in the last 3 volumes of the IDB still include the hydrofracturing values in the entries for "Decayed Radioactivity." Thus, these values are erroneous and should not be used for estimation of radionuclide inventories in buried wastes.

Arithmetic errors (three apparent typographical errors; two of which also occur in Table 16 in Arakawa et al. 1994) in the fission product $\left({ }^{90} \mathrm{Sr},{ }^{137} \mathrm{Cs}\right)$ activity submitted to the IDB resulted in an underestimate (in ORNL 1994a) of the total activity injected amounting to $36,000 \mathrm{Ci}$.

All of this is academic, however, because even if the corrected data had been included in the 1992 IDB compilation these would not have reflected the characteristics of the TRU waste inventories disposed of via hydrofracturing. The reason for this situation is that for the IDB submittal the activities of both ${ }^{233} \mathrm{U}$ and ${ }^{244} \mathrm{Cm}$ were included in calculations of "transuranic" concentrations.

Although the concentrations of ${ }^{233} \mathrm{U}$ in $\mathrm{ORNL}$ wastes are relatively small in relation to those for the long-lived TRU isotopes, concentrations of ${ }^{244} \mathrm{Cm}$ are about three times greater on average than the sum of ${ }^{238} \mathrm{Pu},{ }^{239} \mathrm{Pu}$, and ${ }^{241} \mathrm{Am}$ (Weeren 1984; Arakawa et al. 1994). Inclusion of ${ }^{244} \mathrm{Cm}$ created a situation whereby data for two liquid-LLW injections (ILW-11 in 1972 at the OHF, and ILW-21 in 1984 at the NHF) were included in the TRU waste totals (ORNL 1994a; Arakawa et al. 1994). The radioactivity and volume for the $I \mathrm{~W}-11$ injection were also combined with pre1975 values for buried solid wastes, resulting in some confusion, as noted earlier.

When ${ }^{233} \mathrm{U}$ and ${ }^{244} \mathrm{Cm}$ are not so included, none of the liquid LLW injections and only five of the sludge injections appear to meet the TRU waste criterion (concentration $>100 \mathrm{nCi} / \mathrm{g}$; based on ${ }^{238} \mathrm{Pu}$, ${ }^{239} \mathrm{Pu}$, and ${ }^{241} \mathrm{Am}$ content). However, sludge injection 4 at the NHF yields a transuranic concentration of $99 \mathrm{nCi} / \mathrm{g}$, and probably should be included because uncertainties in measurements make this value indistinguishable from a value $>100 \mathrm{nCi} / \mathrm{g}$. In addition, sludge injection 2 would undoubtedly have met the TRU waste criterion had an ${ }^{241} \mathrm{Am}$ value been reported. Assuming conservatively that the ${ }^{241} \mathrm{Am}$ concentration was equal to that ${ }^{239} \mathrm{Pu}$ (see Table 16 in Arakawa et al. 1994), the TRU concentration would have been $110 \mathrm{nCi} / \mathrm{g}$.

If the waste-grout mixtures for the 7 injections described above are considered TRU wastes, the volume injected becomes $6290 \mathrm{~m}^{3}$ containing $1860 \mathrm{Ci}$ of TRU isotopes $\left({ }^{238} \mathrm{Pu},{ }^{239} \mathrm{Pu}\right.$, and ${ }^{241} \mathrm{Am}$; Table 7). Given the uncertainties introduced by sampling and the state of analytical techniques at the time of the injections, and the fact that the lowest concentration estimate was about $40 \mathrm{nCi} / \mathrm{g}$, one could argue that all of the sludges injected via hydrofracturing are potential TRU wastes. Under this assumption, the volume would increase to $8820 \mathrm{~m}^{3}$ with an associated TRU activity of $2100 \mathrm{Ci}$. Total sludge activities injected at the NHF, which have been corrected for the errors in fission product activities described above, are also shown in Table 7.

For purposes of remedial action planning, the entire waste-grout mixture injected by the NHF has been considered TRU waste (Trabalka 1987). The reasons for this were that the average concentration injected is well in excess of $100 \mathrm{nCi} / \mathrm{g}\left(2100 \mathrm{Ci} ; 10,900 \mathrm{~m}^{3}\right.$; mean density $\left.1.4 \mathrm{~g} / \mathrm{cm}^{3}\right)$ 
Table 7. Recorded radioactivity and volume in TRU-waste sludge-grout mixtures injected at the New Hydrofracture Facility at ORNL, updated from recent data evaluation activities ${ }^{a}$

\begin{tabular}{lll}
${ }^{60} \mathrm{Co}$ & $6.71 \times 10^{3}$ & $5.31 \times 10^{3}$ \\
${ }^{90} \mathrm{Sr}$ & $6.35 \times 10^{5}$ & $5.69 \times 10^{5}$ \\
${ }^{134} \mathrm{Cs}$ & $9.40 \times 10^{1}$ & $3.10 \times 10^{1}$ \\
${ }^{137} \mathrm{Cs}$ & $5.55 \times 10^{4}$ & $4.67 \times 10^{4}$ \\
${ }^{152} \mathrm{Eu}$ & $1.89 \times 10^{3}$ & $1.38 \times 10^{3}$ \\
${ }^{154} \mathrm{Eu}$ & $1.87 \times 10^{3}$ & $1.40 \times 10^{3}$ \\
${ }^{155} \mathrm{Eu}$ & $7.48 \times 10^{2}$ & $6.13 \times 10^{2}$ \\
${ }^{233} \mathrm{U}$ & $2.53 \times 10^{2}$ & $2.47 \times 10^{2}$ \\
${ }^{235} \mathrm{U}$ & $3.00 \times 10^{-1}$ & $2.00 \times 10^{-1}$ \\
${ }^{238} \mathrm{U}$ & 5.00 & 2.20 \\
${ }^{238} \mathrm{Pu}$ & $7.07 \times 10^{2}$ & $6.63 \times 10^{2}$ \\
${ }^{239} \mathrm{Pu}$ & $7.25 \times 10^{2}$ & $6.17 \times 10^{2}$ \\
${ }^{241} \mathrm{Am}$ & $6.71 \times 10^{2}$ & $5.80 \times 10^{2}$ \\
${ }^{244} \mathrm{Cm}$ & $7.51 \times 10^{3}$ & $6.40 \times 10^{3}$ \\
\multicolumn{1}{c}{ Totals } & $7.11 \times 10^{5}$ & $6.33 \times 10^{5}$ \\
\hline
\end{tabular}

${ }^{a}$ Source: Arakawa et al. (1994), with errors in ${ }^{137} \mathrm{Cs}$ values for sludge injections 1 and 2 corrected by substituting $6800 \mathrm{Ci}$ and $2640 \mathrm{Ci}$, respectively (see text). Density $=1.4 \mathrm{~g} / \mathrm{cm}^{3}$.

${ }^{\mathrm{b}}$ Sludge injections $2,3,4,6,8,9$, and 10 . Data for these 7 injections indicate that all should be classified as TRU wastes under the current definition (see text).

${ }^{\mathrm{c}}$ Reporting of radionuclides was incomplete: ${ }^{134} \mathrm{Cs}$ values were reported only for sludge injections 1, 2, and 3; complete $U$ isotopic data were provided only for sludge injections 6 and 7; and ${ }^{241} \mathrm{Am}$ and ${ }^{244} \mathrm{Cm}$ values were not provided for sludge injection 2 .

${ }^{\mathrm{d}}$ Values for ${ }^{239} \mathrm{Pu}$ include ${ }^{240} \mathrm{Pu}$. 
and the nature and depth of the injection process make future segregation moot.

The story does not end here, however. The NHF injection data used by Trabalka (1987) and by Monk (1996) were derived from summary information published by Weeren (1984), which were also utilized in the ORNL RCRA Facility Assessment (ORNL 1987a) and other remedial action planning documents (e.g., Myrick and Stow 1987). There are differences in the radioisotopic activities reported by Weeren (1984) and those in the original data reports (series of ORNL/NFW reports authored by T. N. Tiegs or H. O. Weeren during 1983 and 1984; listed in references in Weeren 1984 and ORNL 1987a). Data from the latter were compiled for the 1992 IDB submittal and are also included in the report by Arakawa et al. (1994).

The currently unanswered question is which data set is the more accurate. Were some errors in the original data reports corrected in the summary table compiled by Weeren (1984)? Or did the summary table contain arithmetic or typographical errors produced during transposition of the values from the original data reports? (The author has assumed the latter.) Fortunately, once typographical and offsetting errors in the two data sets are taken into account, the differences in the fission product inventories amount to a few thousand curies out of $>700,000 \mathrm{Ci}$ injected. In addition, the totals for the long-lived TRU isotopes do not differ significantly in either data set.

Although measurements of hazardous chemical constituents in waste-grout mixtures injected via hydrofracturing are very limited (see Appendix in ORNL 1987a), the characteristics of these materials should be fairly similar to those of the sludges in the Melton Valley Storage Tanks (MVSTs) at ORNL (e.g., Keller 1996b). All of the MVST sludges exceed the total metal limits (20 times the EPA Toxicity Characteristic Leaching Procedure extraction limits) for lead and mercury, and two tanks are over or near the limit for chromium. Most radioactive waste sludge samples from ORNL have exceeded the total metal limits for these three metals (Keller 1996a,b).

\subsection{Other Potential Sources of "Buried" TRU Wastes}

In FY 1987, the ORNL Remedial Action Program (forerunner to the current Environmental Restoration Program) attempted to identify all potential sources of transuranic wastes for planning purposes. The results of the effort were published in ORNL/RAP-8 (Trabalka 1987). In addition to the sources identified above, this report listed as potential sources: Sludges in 24 liquid-LLW storage tanks, contamination in inactive liquid-LLW transfer lines, and contaminated soils associated with 28 leaks from inactive transfer lines and storage tanks. In the majority of cases, site or waste characterization data were not available. Thus, it was not possible to make a clear determination of whether the stored or leaked materials were TRU wastes. However, documentation existed to show that TRU wastes were present in many tanks, potentially in some transfer lines, and at some leak sites. Further, existing plans for remediation of many of these sites were focused on in situ stabilization. Thus, the compilation was considered useful for remedial action planning purposes, i.e., to focus characterization efforts. 
It was also recognized that the waste volumes associated with such sites, even if retrieved in toto, were inconsequential in relation to those in solid waste burial sites, even if "minimum" estimates of wastes and proximate contaminated soils were adopted. Further, the bulk of the potential TRU wastes at these additional sites was associated with tank sludges (Trabalka 1987). Since 1987, however, a comprehensive waste characterization effort has shown that ten of the 24 tanks do not contain TRU waste sludges. And TRU waste sludges in the other 14 tanks are now to be retrieved for treatment and ultimate disposal in the WIPP. Thus, TRU waste sludges in the ORNL tanks are considered stored for planning purposes.

Even given the lack of characterization data for the inactive transfer lines and the leak sites, the fact that their TRU waste content is lost in the noise associated with the SWSAs and the Seepage Pits and Trenches indicates that these need not be considered further in developing estimates of buried TRU waste inventories. This is not to say, however, that such sources should be ignored in risk assessments specific to the waste areas in which these are located. 


\section{CONCLUSIONS AND RECOMMENDATIONS}

It is not surprising that confusion has resulted from intercomparisons of previously published estimates for buried TRU wastes and contaminated soils at ORNL. At the same time, it is difficult to fault the preparers of these estimates for the wide range of differences that have resulted. The major problem is a lack of formal waste characterization. Unfortunately, this is still a significant concern for TRU wastes generated in 1997. Improved characterization of all wastes tentatively identified as TRU wastes at ORNL remains a critical necessity. The complexities of ORNL wastes require that process knowledge, sampling and destructive assay, and nondestructive assay (which requires some technology development for effective deployment) be combined appropriately in order to meet the challenges of waste characterization (Meeks and Chapman 1997; Nguyen, Miller, and Downing 1997).

Given the limited characterization of ORNL wastes, it is not a simple matter to estimate what fraction of post-1969 stored or buried wastes are TRU wastes meeting the current regulatory and legally defined definition: Containing alpha-emitting transuranium radionuclides with half-lives $>20 \mathrm{y}$ in concentrations $>100 \mathrm{nCi} / \mathrm{g}$. Not being able to resolve this issue satisfactorily limits the use of back-extrapolations to estimate a profile for pre- 1970 buried wastes. Back-extrapolations are dependent on having accurate information on post- 1969 buried wastes as a starting point.

Because waste characterization per se was not often conducted for early TRU wastes, many radionuclides were not reported and radionuclide inventories, when reported, were often given as $\leq$ values. Although these two practices generate errors in waste inventories that partially offset one another, the net effects are not currently quantifiable. The effects of these practices may be small when compared to those produced by the undocumented alterations of the original input data for RH-TRU wastes. Changes in the isotopic composition and generation rates of ORNL TRU wastes as a result of changes in major waste-generating R\&D and isotope production activities over time add further uncertainties to pre-1970 estimates based on either back extrapolations or use of accountability records (Sect. 1.1.2).

Although one may still be tempted to use back-extrapolated values in lieu of no information (e.g., by further manipulation of the calculated subtotals in Table 4), it is recommended that pre-1970 buried solid TRU waste be reported to have an unknown volume with an unknown isotopic composition (Table 8).

Even though the best and most current information on recorded estimates for TRU waste burials after 1969 is given in Table 5, the utility of this information appears to be quite limited. The RHTRU wastes buried in SWSA-5 South during 1970-1972 are suspected to be TRU wastes based on very limited data obtained recently from characterization of newly generated wastes (Sect. 2.1.2), but the radionuclide content is considered unknown (Table 8) for the reasons given above. Review of the reported TRU content and volumes for the waste containers disposed of in SWSA 5 North during 1975-1977 suggests that a relatively small fraction may contain TRU wastes (Sect. 
Table 8. Estimates of buried TRU waste inventories produced by liquid or solid radioactive waste disposal at $\mathrm{ORNL}^{\mathrm{a}}$

Sites $\quad \frac{\text { Volume }\left(10^{3} \mathrm{~m}^{3}\right)}{\text { Total TRU waste }} \frac{\text { Total TRU Dadioactivity }\left(10^{3} \mathrm{Ci}\right)}{\text { Disposal dates }}$

Solid Waste Storage Areas

$1,2, \& 3$

$4 \& 5$-South ${ }^{\mathrm{b}}$

5-South

5-North

5-South \& 6

NA

NA

$140^{c}$

Unknown

$0.17^{\mathrm{d}}$

$12^{\mathrm{c}}$

0.40

Unknown $^{\text {d }}$

NA

NA

Seepage Pits and Trenches

Liquid-LLW disposals

210

$\mathrm{NA}^{\mathrm{f}}$

1250

$\mathrm{NA}^{\mathrm{f}}$

1951-1966

Old Hydrofracture Facility

$$
\text { Liquid-LLW injections }
$$

INA

NA

NA

NA

1968-1979

New Hydrofracture Facility

Liquid-LLW injections

Sludge injections

$\begin{array}{clrrr}\text { NA } & \text { NA } & \text { NA } & \text { NA } & 1982-1984 \\ 8.8 & 6.3 & 710 & 1.9^{\mathrm{g}} & 1982-1984\end{array}$

Soils contaminated by:

Solid waste disposal

Liquid waste disposal

Unknown

Unknown

Unknown

Unknown $^{\mathrm{h}}$

Unknown

1951-1977

1951-1984

${ }^{\mathrm{a}} \mathrm{TRU}=$ transuranic; $\mathrm{NA}=$ not applicable because TRU wastes were not disposed of at these sites during the periods indicated (see Sect. 2). 


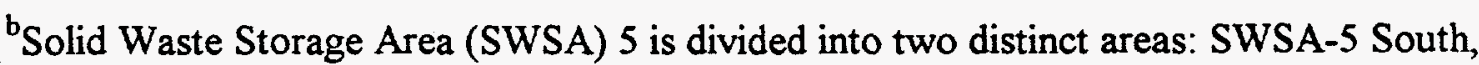
which was used for disposal of low-level and TRU wastes, and SWSA-5 North, which was used mainly for waste storage (Fig. 2). Values given do not include inventories of RH-TRU wastes stored below-grade in the 23-trench 7802N Area of SWSA-5 North (Table 2).

'Source: Bates (1983). Waste generators often provided only $\leq$ values. Thus, total activities may represent upper limits.

${ }^{d}$ Represents total internal volume of the 106 RH-TRU waste containers disposed of. Wastes are suspected to be TRU wastes based on very limited data obtained recently from characterization of newly generated wastes. The waste volume given is a maximum value: Sum of total internal volumes of containers used in default of actual waste volume estimates. The latter are available but have large uncertainties because of the presence of voids (see Sect. 2.1.2).

${ }^{e}$ Review of the reported TRU content and waste volumes for the 63 waste containers disposed of in SWSA 5 North suggests that a relatively small fraction of these may hold TRU wastes (see Sect. 2.1.2). The TRU content given is the total reported for all 63 containers (Table 5).

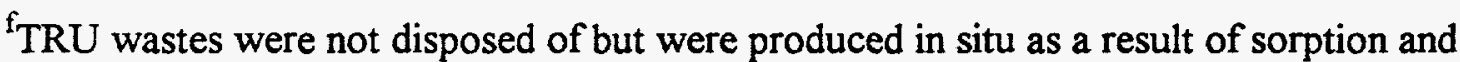
precipitation processes. However, volumes and radionuclide inventories in these residuals have not been measured (see footnote $h$ ).

${ }^{g}$ Approximately $70 \%$ of the waste-grout mixture injected appears to have been TRU waste (Sect. 2.3.2.1). The non-transuranic activity associated with this fraction was about $630,000 \mathrm{Ci}$ (Table 7).

${ }^{h}$ Although the volumes of and radionuclide inventories in the TRU waste residuals have not been determined, current indications are that the bulk of the long-lived radioactivity has not migrated appreciably from the major disposal sites. Thus, a rough estimate of the total radioactivity remaining in LLW Seepage Pits $2-4$ and in Trenches 5 and 7 can be obtained by simply correcting the ${ }^{90} \mathrm{Sr}$ and ${ }^{137} \mathrm{Cs}$ activities in Table 6 for radioactive decay. The same approach can be used with the data from Table 7 to estimate the current inventories in the underground grout sheets produced by the New Hydrofracture Facility. Data for individual TRU . radionuclides are included in Table 7 , but only ${ }^{239,240} \mathrm{Pu}$ values (totaling $53 \mathrm{Ci}$ ) are available currently for the Seepage Pits and Trenches (Table 6). 
2.1.2). The TRU content given in Table 8 is the total reported for all 63 containers and thus could represent an upper limit on the inventory in the fraction that holds TRU wastes.

It is recommended that a set of six 55-gal drums, included as buried wastes in the response to the DOE Carlsbad Area office as part of Rev. 3 to the Baseline Inventory Report for the WTPP (Monk 1996), be removed from the buried waste inventory (see Sect. 2.1.1). Several of these drums were clearly not disposed of, and judgment should be withheld on the remainder until it can be convincingly demonstrated that these were disposed of and their disposal locations can be defined.

Summary level information on TRU waste inventories produced by liquid waste disposal is also provided in Table 8. TRU wastes per se were not disposed of in the LLW Seepage Pits and Trenches but these were produced in situ as a result of sorption and precipitation processes. However, volumes and radionuclide inventories in these residuals have not been measured. It is estimated that about $50 \mathrm{Ci}$ of ${ }^{239,240} \mathrm{Pu}$ may be associated with these residuals (see below).

Approximately $70 \%$ of the waste-grout mixture injected at the NHF appears to have been TRU waste (Table 8: Sect. 2.3.2.1). The TRU and non-TRU activities associated with the TRU waste fraction were about $1900 \mathrm{Ci}$ and $630,000 \mathrm{Ci}$, respectively (Tables 7 and 8 ). However, given that the average composition of the entire waste-grout mixture injected meets the TRU-waste criteria and the nature and depth of the injection process, segregation of the TRU- and non-TRU-waste fractions appears to be moot.

The volume and TRU radioactivity in TRU-contaminated soils should also be reported as having an unknown volume with an unknown isotopic composition (Table 8). Although the volumes of and radionuclide inventories in the TRU waste residuals have not been determined, current indications are that the bulk of the long-lived radioactivity has not migrated appreciably from the major liquid waste disposal sites. Thus, a rough estimate of the total radioactivity remaining in LLW Seepage Pits $2-4$ and in Trenches 5 and 7 could be obtained by simply correcting the ${ }^{90} \mathrm{Sr}$ and ${ }^{137} \mathrm{Cs}$ activities in Table 6 for radioactive decay. The same approach could be used with the data from Table 7 to estimate the current inventories in the underground grout sheets produced by the New Hydrofracture Facility. Data for individual TRU radionuclides are included in Table 7, but only ${ }^{239,240} \mathrm{Pu}$ values (totaling $53 \mathrm{Ci}$ ) are available currently for the Seepage Pits and Trenches (Table 6). Each of these sets of data carries additional uncertainties related to the level of waste sampling conducted, as described in Sect. 2.3.

Finally, it is recommended that, as time and resources permit, all original records for TRU wastes - stored and buried - be cross-checked against the Waste Tracking System data base to correct transcription errors of the type uncovered by this review. It is likely that additional errors remain to be corrected. Although this activity is unlikely to produce major changes in the waste inventories, it will increase the overall level of confidence in the data base. Given the questions about the quality of the information in some of the original records and their relationship to the data base records, however, such an effort should not command significant resources. 


\section{ACKNOWLEDGEMENTS}

The author would like to thank R. J. Robinette for information and advice on historical records associated with waste disposal at ORNL, M. S. Condon for providing access to information in the ORNL Waste Tracking System data base, and B. C. McClelland for assistance in resolving the status of a cohort from the buried waste inventory. He also wishes to thank J. S. Baldwin and T. $\mathrm{H}$. Monk for providing technical review comments. 


\section{REFERENCES}

Arakawa, P.E., R. L. Pearson, D. W. Turner, and M. J. Cole-Yocom. 1994. Transuranic Waste at Oak Ridge National Laboratory: Inventory, characteristics, and projection as of December 31, 1992. ORNL/TM-12700. Oak Ridge National Laboratory, Oak Ridge, Tennessee.

Bates, L. D. 1983. Radioactive solid waste storage and disposal at Oak Ridge National Laboratory: Description and safety analysis. ORNL/TM-8201. Oak Ridge National Laboratory, Oak Ridge, Tennessee.

Beauchamp, J., D. Downing, J. Chapman, V. Fedorov, L. Nguyen, C. Parks, F. Schultz, and L. Yong. 1996. Statistical analysis of radiochemical measurements of TRU radionuclides in REDC waste. ORNL/TM-13298. Oak Ridge National Laboratory, Oak Ridge, Tennessee.

Coobs, J. H., and J. R. Gissel. 1986. History of disposal of radioactive wastes into the ground at Oak Ridge National Laboratory. ORNL/TM-10269. Oak Ridge National Laboratory, Oak Ridge, Tennessee.

ERDA (U.S. Energy Research and Development Agency). 1976. Alternatives for Managing Wastes from Reactors and Post-Fission Operations in the LWR Fuel Cycle, ERDA 76-43, Volume 4: Alternatives for Waste Isolation and Disposal, Table 24.6, p. 24.20. ERDA, Washington, D.C.

Everette, S. E., J. A. Detamore, M. H. Raudenbush, and R. E. Thieme. 1988. Comprehensive implementation plan for the DOE Defense Buried TRU-Contaminated Waste Program. DOE-TRU TECH-001. The Joint Integration Office, U. S. Department of Energy, Albuquerque, New Mexico.

H\&R (H\&R Technical Associates, Inc.). 1997. Assessment of classified waste information for CERCLA decisions at Melton Valley and Bethel Valley Watersheds, Oak Ridge National Laboratory, Oak Ridge, Tennessee. ORNL/ER-411. Oak Ridge National Laboratory, Oak Ridge, Tennessee.

Jolley, R. L., R. K. Genung, L. E. McNeese, and J. E. Mrochek. 1994. The ORNL Chemical Technology Division: 1950-1994. ORNL/M-2733/R1. Oak Ridge National Laboratory, Oak Ridge, Tennessee.

Keller, J. M., J. M. Giaquinto, and W. H. Griest. 1996a. Characterization of selected waste tanks from the active LLLW system. ORNL/TM-13248. Oak Ridge National Laboratory, Oak Ridge, Tennessee. 
Keller, J. M., J. M. Giaquinto, and A. M. Meeks. 1996b. Characterization of the MVST waste tanks located at ORNL. ORNL/TM-13357. Oak Ridge National Laboratory, Oak Ridge, Tennessee.

King, E. M. 1981a. Letter to L. J. Smith, TRU Waste Systems Office, Rockwell International, Golden, Colorado, "TRU Waste Data." January 7, 1981. Oak Ridge National Laboratory, Oak Ridge, Tennessee.

King, E. M. 1981b. Letter to S. S. Martin, TRU Waste Systems Office, Rockwell International, Golden, Colorado, "Rocky Flats TRU Waste Survey." June 24, 1981. Oak Ridge National Laboratory, Oak Ridge, Tennessee.

King, E. M. 1982. Letter to R. T. Jensen, Energy Systems Group, Rockwell International, Golden, Colorado, "Re: Answers to Input Request for 1982 Department of Energy Integrated Data Base - Transuranic Waste Sections Only." February 22, 1982. Oak Ridge National Laboratory, Oak Ridge, Tennessee.

King, E. M. 1985. Letter to D. R. Brown, U. S. Department of Energy, Oak Ridge, Tennessee, "TRU Waste Inventory and Projection Data." February 28, 1985. Oak Ridge National Laboratory, Oak Ridge, Tennessee.

Lomenick, T. E., D. G. Jacobs, and E. G. Struxness. 1967. The behavior of strontium-90 and cesium-137 in seepage pits at ORNL. Health Physics 13: 897-905.

Lotts, A. L. 1979. Letter to D. E. Large, U. S. Department of Energy, Oak Ridge, Tennessee, "Pending GAO Review of DOE Radioactive Waste Management Programs." February 26, 1979. Oak Ridge National Laboratory, Oak Ridge, Tennessee.

Meeks, A. M., and J. A. Chapman. 1997. Development of the remote-handled transuranic waste radioassay data quality objectives. ORNL/TM-13362. Oak Ridge National Laboratory, Oak Ridge, Tennessee.

Monk, T. H. 1996. Letter to D. Watkins, U. S. Department of Energy, Carlsbad, New Mexico, "Revision 3 Transuranic Baseline Inventory Report, Attachment 3: Information on Previously Disposed TRU Waste on the Oak Ridge Reservation." June 14, 1996. Oak Ridge National Laboratory, Oak Ridge, Tennessee.

Myrick, T. E., and S. H. Stow. 1987. Remedial Action Plan for ORNL Hydrofracture Operations. ORNL/RAP-9. Oak Ridge National Laboratory, Oak Ridge, Tennessee.

NAS (National Academy of Sciences). 1985. The Management of Radioactive Wastes at Oak Ridge National Laboratory: A Technical Review. National Academy Press, Washington, 
D.C.

Nguyen, L. K. 1997. Characterization of ORNL transuranic waste from the measurement of fission and activation products. M.S. Thesis, The University of Tennessee, Knoxville.

Nguyen, L. K., L. F. Miller, and D. J. Downing. 1997. Measurements of fission and activation products for Oak Ridge National Laboratory transuranic waste characterization. ORNL/TM-13292. Oak Ridge National Laboratory, Oak Ridge, Tennessee.

Olsen, C. R., P. D. Lowry, S. Y. Lee, I. L. Larsen, and N. H. Cutshall. 1983. Chemical, geological, and hydrological factors governing radionuclide migration from a formerly used seepage trench: A field study. ORNL/TM-8839. Oak Ridge National Laboratory, Oak Ridge, Tennessee.

ORNL (Oak Ridge National Laboratory). 1980. Spent Fuel and Waste Inventories and Projections. ORO-778. U. S. Department of Energy, Oak Ridge Operations Office, Oak Ridge, Tennessee

ORNL. 1984. Spent Fuel and Radioactive Waste Inventories, Projections, and Characteristics. DOE/RW-0006. U. S. Department of Energy, Washington, D.C.

ORNL. 1985. Spent Fuel and Radioactive Waste Inventories, Projections, and Characteristics. DOE/RW-0006, Rev. 1. U. S. Department of Energy, Washington, D.C.

ORNL. 1986. CERCLA Phase I Report: Identification and preliminary assessment of inactive hazardous waste disposal sites and other contaminated areas at ORNL. ORNL/TM-9989. Oak Ridge National Laboratory, Oak Ridge, Tennessee.

ORNL. 1987a. RCRA Facilities Assessment (RFA)-Oak Ridge National Laboratory. ORNL/RAP-12/V1. Oak Ridge National Laboratory, Oak Ridge, Tennessee.

ORNL. 1987b. Buried TRU wastes and TRU-contaminated soils at Oak Ridge National Laboratory. ORNL/RAP-24. Oak Ridge National Laboratory, Oak Ridge, Tennessee.

ORNL. 1991. Integrated Data Base for 1991: U.S. Spent Fuel and Radioactive Waste Inventories, Projections, and Characteristics. DOE/RW-0006, Rev. 7. U. S. Department of Energy, Washington, D.C.

ORNL. 1992. Integrated Data Base for 1992: U.S. Spent Fuel and Radioactive Waste Inventories, Projections, and Characteristics. DOE/RW-0006, Rev. 8. U. S. Department of Energy, Washington, D.C.

ORNL. 1994a. Integrated Data Base for 1993: U.S. Spent Fuel and Radioactive Waste 
Inventories, Projections, and Characteristics. DOE/RW-0006, Rev. 9. U. S. Department of Energy, Washington, D.C.

ORNL. 1994b. Integrated Data Base Report-1993: U.S. Spent Nuclear Fuel and Radioactive Waste Inventories, Projections, and Characteristics. DOE/RW-0006, Rev. 10. U. S. Department of Energy, Washington, D.C.

ORNL. 1995a. Integrated Data Base Report-1994: U.S. Spent Nuclear Fuel and Radioactive Waste Inventories, Projections, and Characteristics. DOE/RW-0006, Rev. 11. U. S. Department of Energy, Washington, D.C.

ORNL. 1996. Integrated Data Base Report-1995: U.S. Spent Nuclear Fuel and Radioactive Waste Inventories, Projections, and Characteristics. DOE/RW-0006, Rev. 12. U. S. Department of Energy, Washington, D.C.

ORNL Environmental Restoration Program. 1995. Remedial investigation report on Waste Area Grouping 5 at Oak Ridge National Laboratory, Oak Ridge, Tennessee. 4 vols. DOE/OR/01-1326\&D2, ORNL/ER-284\&D2, ORNL/ER/Sub/87-99053/76. Oak Ridge National Laboratory, Oak Ridge, Tennessee.

Row, T. H. 1983. Letter to D. R. Brown, U. S. Department of Energy, Oak Ridge, Tennessee, "TRU Waste Inventory and Projection Data." March 2, 1983. Oak Ridge National Laboratory, Oak Ridge, Tennessee.

Row, T. H. 1984. Letter to D. E. Large, U. S. Department of Energy, Oak Ridge, Tennessee, "TRU Waste Inventory and Projection Data." April 6, 1984. Oak Ridge National Laboratory, Oak Ridge, Tennessee.

Spalding, B. P. 1987. Environmental data package for the ORNL Seepage Pits and Trenches Waste Area Grouping. ORNL/RAP-10. Oak Ridge National Laboratory, Oak Ridge, Tennessee.

Stewart, R. C., L. S. Dickerson, S. F. Joost, and D. C. Osucha. 1989. Remote-handled transuranic solid waste characterization study: Oak Ridge National Laboratory. ORNL/TM-11050. Oak Ridge National Laboratory, Oak Ridge, Tennessee.

Trabalka, J. R. 1987. Buried TRU wastes and TRU-contaminated soils at ORNL Remedial Action Program sites: Program strategy and long-range planning. ORNL/RAP-8. Oak Ridge National Laboratory, Oak Ridge, Tennessee.

Webster, D. A. 1976. A review of the hydrologic and geologic conditions related to the radioactive solid-waste burial grounds at Oak Ridge National Laboratory, Tennessee. Open-file report 76-727. U.S. Department of the Interior, Geological Survey, Knoxville, 
Tennessee.

Weeren, H. O. 1984. Hydrofracture injections at Oak Ridge National Laboratory - 1982-1984 Series. ORNL/NFW-84/43. Oak Ridge National Laboratory, Oak Ridge, Tennessee.

Weeren, H. O., L. C. Lasher, and E. W. McDaniel. 1985. Cleanout of waste storage tanks at Oak Ridge National Laboratory. In C. M. Jantzen, J. A. Stone, and R. C. Ewing (Eds.), Scientific Basis for Nuclear Waste Management VIII. Materials Research Society Symposia Proceedings, Vol. 44. Materials Research Society, Pittsburgh, Pennsylvania.

Y-12 Plant (Oak Ridge Y-12 Plant). 1984. Inventory of disposals conducted at ORNL burial sites from the Y-12 Plant (U): February 1957 through August 1983. Y/DS-196. Production Optimization Department, Oak Ridge Y-12 Plant, Oak Ridge, Tennessee. 


\section{APPENDIX A. ADDITIONAL REFERENCE MATERIALS}

1. Memo from L. D. Bates to E. M. King, Operations Division, Oak Ridge National Laboratory, Oak Ridge, Tennessee, "Waste Characterization Information Supplied to TWSO, Rocky Flats Plant." May 16, 1980

2. Memo from E. M. King, Operations Division, Oak Ridge National Laboratory, Oak Ridge,Tennessee, to File, "TRU Waste Data for Integrated Data Base - Answer to Smith's Letter Dated 1 Dec 1980 -- Source of Info and Calc." January 7, 1981

3. Memo from J. D. Sease to T. H. Row, Nuclear Waste Programs, Oak Ridge National Laboratory, Oak Ridge,Tennessee, "Follow-Up Visit of Ed Slaven, Appalachian Observer, October 14, 1982." November 5, 1982 A-6 


\section{INTRA-LABORATORY CORRESPONDENCE \\ OAK RIDGE NATIONAL LABORATORY}

May 16,1980

To: $\quad$ E. M. King

Subject: WASTE CHARACTERIZATION INFORMATION SUPPLIED TO TWSO, ROCKY FLATS PLANT

Per request from Tom Scott, TWSO, the following information was supplied (midApri1) in regard to stored and buried transuranic waste at ORNL. This information was relayed by TWSO to DOE-ALO to be used, along with information from other sites, in making decisions on the TRU Waste Alternatives Assessment/EIS Program.

1. Current Waste Volume and Number of Containers

Nonretrivable (buried) - $220,000 \mathrm{ft}^{3}\left(6,230 \mathrm{~m}^{3}\right) \pm 50 \%$

Retrievable (stored)

\begin{tabular}{|c|c|c|c|}
\hline Type & Number & $m^{3}$ & $\mathrm{Ft}^{3}$ \\
\hline $\begin{array}{l}\text { Stainless Steel Drums } \\
\text { Black Iron Drums } \\
\text { Concrete Casks } \\
\text { SS Lined Wells }\end{array}$ & $\begin{array}{r}1,282 \\
277 \\
189 \\
30\end{array}$ & $\begin{array}{r}348.6 \\
537.5 \\
3.7 \\
\end{array}$ & $\begin{array}{rr}12,312 & (\mathrm{CH}) \\
19,103 & (\mathrm{RH}) \\
130 & (\mathrm{RH}) \\
\end{array}$ \\
\hline & & 889.8 & $31,54.5$ \\
\hline
\end{tabular}

2. Estimated Waste Volume in 1990

Estimated 10 Year Generation Rate:

Contact Handled Waste $-2,500 \mathrm{ft}^{3} /$ year

Remote Handled Waste $-2,500 \mathrm{ft}^{3} /$ year

$\mathrm{CH}$ Waste: Current - 12,312

Generation - 25,000

$199037,312 \mathrm{ft}^{3}\left(1,056 \mathrm{~m}^{3}\right)$

RH Waste:

Current - 19,233

Generation - $\underline{25,000}$

$44,233 \mathrm{ft}^{3}\left(1,252 \mathrm{~m}^{3}\right)$

Total in $1990 \quad 81,545 \mathrm{ft}^{3}\left(2,308 \mathrm{~m}^{3}\right)$ 
3. Isotopic Content

Primary transuranics in buried and stored waste are $\mathrm{U}^{233}$ and Pu.

Buried Waste: U233 $3.5 \mathrm{~kg}$

(Estimates) $\mathrm{Pu} \quad \underline{1.7} \mathrm{~kg}$

$5.2 \mathrm{~kg}$

Stored Waste: $\mathrm{U}^{233} 8.2 \mathrm{~kg}$

(Estimates) $\mathrm{Pu} \quad \underline{0.3}$

$8.5 \mathrm{~kg}$

Other TRU isotopes are found in lesser quantities along with numerous non-TRU isotopes.

4. Radiation Level at Surface

Drums: All less than $200 \mathrm{mr} / \mathrm{hr}$ (operating requirement) (most are on the order of $10 \mathrm{mr} / \mathrm{hr}$ or less)

Casks: Generally less than $200 \mathrm{mr} / \mathrm{hr}$ (not required) (some casks may read several $\mathrm{R} / \mathrm{hr}$ in places)

Capsules: Large variation - generally $1 \mathrm{k} / \mathrm{hr}-1,000 \mathrm{R} / \mathrm{hr}$

The volumes above are based on records through December 31,1979 . If there are any inaccuracies, please inform me so that I can make the appropriate corrections.

LDB:am

cc: J. H. Coobs

T. Grizzard

R. A. Robinson

LDB File 
T. Tisile

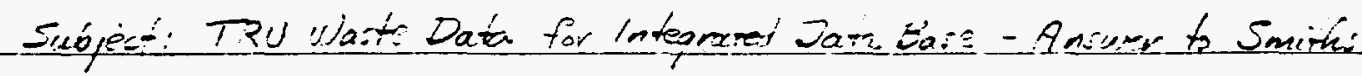
Letter Dated, DeC 1980 .. Source of Info E Calc

L For buried TRU wasts.

a. $\sim 6228 \mathrm{~m}^{3}\left(\sim 220,000 \mathrm{f}^{3}\right)$ - Letter Bates to King dated May 16,1980

(aqrees isth provious swemissicini)

b. $\sim 18,000 \mathrm{~m}^{3}\left(600,000 \mathrm{ft}^{3}\right)$ - This is $\mathrm{N} 3 \mathrm{x}$ the aoove figure for waste buried,

estimating that about 2 added $m^{3}$ may be contaminated fram each $m^{3}$ buried.

c. $5.2 \mathrm{~kg}$ (Frow is Accounrab.tity: $3.5 \mathrm{~kg} U-233+1.7 \mathrm{~kg} P_{\mathrm{u}}$ )

d. $1000 \mathrm{~m}^{3}$ (From =urves of record - 2822 - by Grizard from Lasher info) 2726

e. $0.3 \mathrm{~kg}$ (Estimaty that this sil is about as contaminaied as the

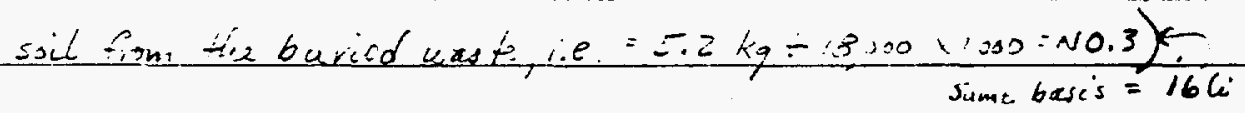

2. For retrievably =-torey $T R U$ urasto

a. $369.8 \mathrm{~m}^{3}\left(13,063 \mathrm{ft}^{3}\right)$ (Quartedy report for July-Sept 1990) b. $41.5 \mathrm{~kg}$ - ..........

c. $561 \mathrm{~m}^{3}\left(19,816 \mathrm{ft}^{3}\right)$

d. $4.1 \mathrm{~kg}$

e. None

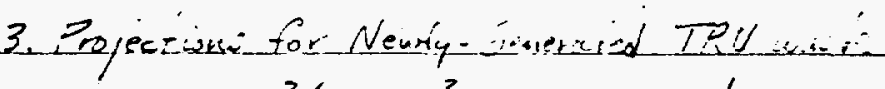

a. $43 \mathrm{~m}^{3}\left(1500 \mathrm{ft}^{3}\right.$ or 188 drums/yr $=$ based su iw toryt contg $\left.y\right)$.

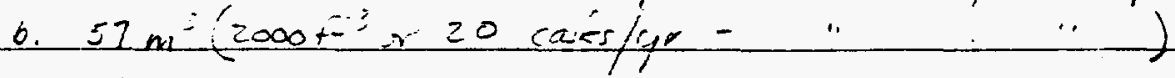

c. Isnce

d. Cumulative Land Hition for Retion (fran 1920)

$$
\text { (next page) }
$$


$|-7-8|$

EMK

d. Contact'inandied.

$$
\begin{aligned}
& 39^{\prime} \times 57^{\prime} \text { (Blig size) }+10 \text { ft on each side }= \\
& 59 \times 77^{\prime}=4543 \pm 43,560=0.104 \text { acres } \\
& \div 2.41=0.0421 \text { hactars 's preen' (end of FY 80) }
\end{aligned}
$$

for $N 400 \mathrm{~m}^{3}$ or 0.01 hectares $/ 100 \mathrm{~m}^{3}$

Af $43 \mathrm{~m}^{3} / \mathrm{yc}=00.02$ hechared $/ 5$ years.

Contect handicte $\frac{1980}{0.04}-\frac{1985}{0.06}-\frac{1990}{0.08}-\frac{1995}{0.10}-\frac{2000}{0.12}$

Remore irandled

stored in-trencies = 18?

Space = frencle $\sim 7^{\prime} \times 50^{\prime}=11$ caoks $+10^{\prime}=17 \times 60=1020 / 11$ cooks

$187 \div 11=17 \times 1020=17340$

$\div 43,560=0.398$ acres $\div 2.471=0.16$ hectore

Stored in Pidg

$$
\begin{aligned}
7855 & \div 46^{\prime} \times 63^{\prime}+10^{\prime} \text { ow each side } \\
& =66^{\prime} \times 83^{\prime}=5478 \mathrm{ft}^{2} \\
\div 43,560 & =0.126 \text { asres } \div 2.471=0.051 \text { hectares for } 108 \mathrm{couks}
\end{aligned}
$$

at 20 casks $/ y r=00.05$ hectares $/ 5$ years.

Remute handled $\frac{1980}{0.17}-\frac{1985}{0.22}-\frac{1990}{0.27}-\frac{1995}{0.32} \frac{2000}{0.37}$

$1980=0.16+\frac{12}{108} \times 0.05=.006=0.17$

A-5 
INTRA-LABORATORY CORRESPONDENCE

OAK RIDGE NATIONAL LABORATORY

November 5, 1982

To: T. H. Row

From: J. D. Sease

Subject: Follow-Up on Visit of Ed Slaven, AppaTachian Observer, October 14, 1982

The location of the burial sites for the UCC-ND are shown on the enclosed photograph of the TVA map S-16A which is of the Oak Ridge Reservation. While it shows a bit more information than we would normally want to release, it shouid suffice. Some of the areas shaded in grey are the burial sites. Our Solid Waste Storage Area (SWSA) Nos. 1, 2 , and 6 are not shown in grey, Nos. 3,4 , and 5 are. The locations by plant are:

1. The $K-25$ burial sites are ninimal as far as waste storage areas are concerned. Their two sites are within the perimeter fence of the plant, generally in the square $\mathrm{C}-5$.

2. The $Y-12$ sites are located east of the $Y-12$ Plant in Bear Creek Vailey. They are shown in $D-10, D-11, E-10$, and $E-11$.

3. ORNL's facilities are located in squares F-7 (SWSA 3), F-8 (SWSAs 1 and 2), G-7 (SWSAs 4 and 5), and G-6 east of White wing Road just north of white Dak Lake (SWSA 6).

The following information is arranged to coincide with the order of the requests in your October 15 correspondence. 
Pre-1970 TRU waste mixed with beta-gamma:

$26230 \mathrm{~m}^{3}\left(\sim 220,000 \mathrm{ft}^{3}\right)^{a, b}$ in SiUSAs $3,4,5$.

This contains $G .2 \mathrm{~kg}$ of $\operatorname{TRU}(3.5 \mathrm{~kg} 233 \mathrm{U}$ plus $1.7 \mathrm{~kg} \mathrm{Pu})$.

Prior 1963 volumes, acres, curies, dates:

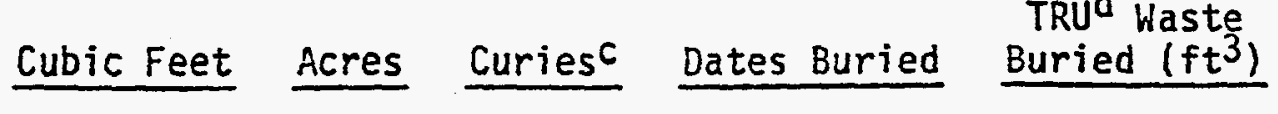

SWSA 1

$\left.\begin{array}{lll}\text { SWSA } & 1 \\ \text { SHSA } & 2 \\ \text { SWSA } & 3\end{array}\right\}$

SWSA 4

SWSA 5

SHSA 6

$$
\begin{array}{r}
100,000 \\
700,000 \\
2,000,000 \\
3,200,000 \\
700,000
\end{array}
$$

5
6
23
50
7

$6,000 \quad 1943-1946$

47,000 1946-1951

$105,000 \quad 1951-1959$

221,000 1959-1971e

1971

a In Integrated Data Base.

becognized to be accurate to $\pm 50 \%$.

cpublished in SWIMS.

dRatioed to total volume buried.

eBurial through 1971, still used for TRU storage (retrievable).

If this is not sufficient, please let me know.

JDS:JRG:rIC 


\section{APPENDIX B. DESCRIPTION OF RH-TRU WASTES FROM THE REDC}

COMBUSTIBLES: Plastics (filters, bottles, tubing, valves, etc), cellulosics, manipulator boots, and elastomers.

With the exception of manipulator boots, combustible materials have contamination levels that are as high or higher than non-combustible materials.

- Polypropylene filters containing process residues (of varying dimensions: about 2.5" dia and up to 10" long) are used to protect equipment (e.g., pumps, valves, ion exchange resins) and prevent particulates from interfering with separations processes. These are the most difficult components from a management standpoint. It currently does not apear to be possible to estimate contaminant loading of the filters by performing a mass balance calculation, i.e., using analyses of liquid samples taken upstream and downstream of the filters. Thus, it appears that there may be no alternative to performing destructive assays on the filters themselves to provide information needed for waste characterization.

Each transuranium element (HFIR or $\mathrm{Cm}$ ) target campaign typically produces 1-2 highlycontaminated filters (dissolver product filters, containing mainly fission products) with an external dose rate on the order of $10,000 \mathrm{R} / \mathrm{h}$ (measured at $6 "$ ). These are held in small stainless steel (SS) containers (about 4" dia by 12 "long) for 4-6 y to reduce the dose rate by decay to $<2000 \mathrm{R} / \mathrm{h}$ measured at contact with the container. Then these are transferred to a 12-in-thick-walled concrete cask of RH-TRU waste for storage.

Similar containers of filters are generated from processing of MARK-42 targets: One for each dissolution. The dose rates are expected to be less initially (perhaps $<2000 \mathrm{R} / \mathrm{h}$ at contact) because of radioactive decay over $>10 \mathrm{y}$ in storage prior to processing. However, because the principal gamma-emitting fission product on the filters is ${ }^{137} \mathrm{Cs}$, a much slower decline in dose rate during storage is to be expected (i.e., given the $30-y$ halflife of ${ }^{137} \mathrm{Cs}$ ).

On the order of 20-30 less-contaminated polypropylene filters are also generated during a campaign. Dose rates from some of these filters fall in the $10-100 \mathrm{R} / \mathrm{h}$ range. For the past $2 \mathrm{y}$, less-contaminated filters have been mixed with polyethylene items in a 1-gal paint can and melted into $0.7-0.8$-gal cylinders as an additional volume reduction step. These filters (with dose rates $\leq 10 \mathrm{R} / \mathrm{h}$ at $\mathrm{l}^{\prime}$ ) are used to remove particulates from cell sump solutions, which are produced primarily from equipment rack and floor decontamination activities. (Melting of other, less-contaminated plastic items has been practiced for about $10 \mathrm{y}$.)

All plastic which is to be melted is monitored to exclude materials that might have recoverable product material or that would produce an intensively radioactive melt product. It has not been possible thus far to produce aggregate melts that meet the $\mathrm{CH}$ - 
TRU waste dose rate limits ( $<200 \mathrm{mR} / \mathrm{h}$ at contact). Typically, the more realistic goal is to keep the dose rate from the melted plastic below REDC limits for direct handling of RH-TRU waste during the process of removal from the hot cells.

- Plastic bottles and other plastic items (primarily polyethylene, but also teflon, PVC, tygon, etc.) are typically flushed or leached well to recover product material, i.e., particularly if if the external neutron dose rate is $>50 \mathrm{mR} / \mathrm{h}$. Thus, the potential for additional decontamination of such items prior to thermal reduction may be limited. Melting items such as bottles that are initally $\mathrm{CH}$-TRU wastes may produce an aggregate that exceeds the $\mathrm{CH}$-dose limit, thus becoming RH-TRU waste.

- Cellulosics (primarily wipes, some cheese cloth, small amount of blotter paper, wood, etc.) also are projected to have a limited potential for decontamination prior to treatment.

- Manipulator boots: Polyurethane with Hypalon coating. Melting temperature is greater than for polyethylene. Level of combustibility is also an issue. Also see discussion on aluminum port rings under non-combustible materials.

- $\quad$ Elastomers are used in gaskets (polyvinylchloride-based) and in O-rings (ethylenepropylene). The former are rinsed before being disposed of.

NONCOMBUSTIBLES: High efficiency particulate air (HEPA) filters in SS housings (varying in size, level of contamination); Tank Pit wastes; equipment racks (made of metal); removeable components from equipment racks made of metal, glass, and plastic, such as valves, pumps, glass pot items, ion exchange columns, fittings, etc.; glass; tools; furnaces; Iodine Retention System beds; calcined ion exchange resins; SS cans; galvanized cans (waste buckets); aluminum port rings for manipulator boots; and other miscellaneous materials such as discarded metal tubing, electrical and signal wire, electronic equipment (preamplifier cans for alpha and neutron detectors), etc.

- HEPA filters are grouped into in-cell and exterior units. One set of in-cell filters (about 6" dia by 8 " long, with an 8" flange; metal and fiberglas construction) has been replaced in the past $5 \mathrm{y}$, but this may not be indicative of the expected future replacement rate. Exterior HEPA filters are much larger and are also changed out infrequently: 2 vessel offgas (VOG) filters (measuring about $2.5^{\prime}$ by $5^{\prime}$ by $2.5^{\prime}$ in aggregate) every $5 \mathrm{y}$, and 4 cell off-gas filters ( $7^{\prime}$ by $2.5^{\prime}$ by $\left.5.5^{\prime}\right)$ about once each decade. The external dose rates from such contaminated filters may be $\geq 10 \mathrm{R} / \mathrm{h}$ (e.g., measured at the unshielded face of some VOG filters), but their physical configuration requires packaging in large boxes rather than in RH-TRU waste casks. In the past, concrete was poured into some boxes to provide additional shielding.

- Tank Pit wastes include small processing tanks (18 to $250 \mathrm{~L}$ ) and discarded piping (Zircaloy-2, Hastelloy-C, SS, tantalum, or titanium), and equipment frames such as the 
cubicle-to-Tank Pit line bundles resulting from periodic maintenance/replacement activities. Although large Tank Pit waste items (e.g., tanks, frames) have not been generated since the 1970s, the potential need for maintenance or replacement of Tank Pit equipment exists at virtually any time. Many potential waste items are too large to fit into 55-gal drums, or, in some cases, into either Standard Waste Boxes or concrete casks without size reduction.

- Equipment racks consist of frames, piping, and removable parts: Valves, pumps, etc. (see below). The removeable parts have almost always been stripped from a rack before the frame is disposed of. (At times, components not originally intended for removal have also been removed.) Thus, when a rack is removed as waste, what is left is primarily the frame, the internal piping, and the base plates for the removable components. The SS frames measure about $3^{\prime}$ by $1.5^{\prime}$ by $6.5^{\prime}$. Piping is made up of Zircaloy-2, tantalum, and/or SS; hastelloy will also be used in future. Racks and cell floors are routinely decontaminated with solutions of $\mathrm{HNO}_{3}$ and $\mathrm{NaOH}$ after each campaign and on a nonroutine basis following spills. Racks are flushed both internally and externally with decontamination solutions.

No racks have entered the waste stream since 1978 , but some will have to be changed out in the near future (including one in 1997). Racks have been decontaminated in the past before removal, and racks can potentially be sawed into pieces, if need be, for size reduction. The potential for decontamination to $\mathrm{CH}$-levels could be explored.

- Removable parts from racks, primarily valves and pumps, but also glass pot items, ion exchange columns, fittings, etc., enter the solid waste stream more frequently as a result of rack maintenance and repairs, i.e., as the individual components fail. Valves can be plastic or combinations of metal and plastic. Valves and pumps are considered the most difficult items to decontaminate because disassembly is needed for effective flushing/leaching. Some, but not all valves, could be disassembled for cleaning.

Most of the removable or replaceable items on equipment racks are smaller - some significantly smaller - than the in-cell conveyer bucket (which is about 10" diameter by 9" high) to facilitate eventual removal. However, some removeable items, such as ion exchange columns, are too elongated (30" to $\left.42^{\prime \prime}\right)$, and 5-L glass tanks are simply too large, to fit within the bucket volume.

- Contaminated tools (mostly SS) are produced by cell maintenance and repair operations.

- Glass enters solid waste streams in the form of bottles, filters, light bulbs, etc. Glass items are occasionally decontaminated in-cell in 3- to 4-L SS trays.

- Small furnaces of metal-ceramic construction are generated ocasionally. One is used to melt polyethlyene, another is used to calcine (1) spent ion exchange resins and (2) $\mathrm{Cm}$ 
oxalate to produce $\mathrm{Cm}$ oxide, and yet another to sinter $\mathrm{Cm}$ oxide prior to blending with $\mathrm{Al}$ for new HFIR targets. The dimensions of the largest furnace are about 20 " by 20 " by 10 ."

- Iodine Retention System beds consist of 3 Hopcalite $^{\mathrm{TM}}$ (mixed manganese and copper oxide catalyst) reaction beds (which measure 6 " by 24 " by 24 ") and 2 charcoal reaction beds ( $24 "$ cubes) plus other miscellaneous materials used to filter process off-gases.

- SS cans used as packaging for shipping can also enter the waste stream on occasion,

- Aluminum port rings for the manipulator boots are the least-contaminated of the noncombustible items. Currently, these are not removed from the boot. Thus, the boots and rings are removed as a unit; virtually all of these are CH-TRU wastes. 


\section{INTERNAL DISTRIBUTION}

1. L.V. Asplund

2. J. S. Baldwin

3. K. A. Balo

4. C. A. Bednarz

5. J. A. Chapman

6. K. N. Constant

7. K. W. Cook

8. D. G. Cope

9. A. F. Diefendorf

10. K. G. Edgemon

11. J. K. Gilpin

12. D. F. Hall

13. T. E. Kent

14. R. H. Ketelle

15. A. J. Kuhaida, Jr.

16. R. C. Mason

17. B. C. McClelland

18. J. F. McCarthy

\author{
19-21. T. H. Monk \\ 22. T. W. Morris \\ 23. T. E. Myrick \\ 24. C. T. Rightmire \\ 25. S. M. Robinson \\ 26. T. F. Scanlan \\ 27. F. J. Schultz \\ 28. B. P. Spalding \\ 29. R. C. Stewart \\ 30. S. N. Storch \\ 31-37. J. R. Trabalka \\ 38. J. D. Tauxe \\ 39. S. M. Trotter \\ 40. D. W. Turner \\ 41. H. D. Wooten \\ 42. Central Research Library \\ 43. Laboratory Records - RC \\ 44-45. Laboratory Records Department - OSTI
}

\section{EXTERNAL DISTRIBUTION}

46. Philip Altomare, U.S. Department of Energy, EM-35, Building TREV, Germantown, MD 20874

47. Michael Brown, Waste Isolation Pilot Plant, U.S. Department of Energy, P. O. Box 3090, Carlsbad, NM 88221

48. Sherry Gibson, U.S. Department of Energy, Federal Building, Oak Ridge TN 37830

49. Clayton Gist, U.S. Department of Energy, 3 Main, Oak Ridge TN 37830

50. Cavanaugh S. Mims, U.S. Department of Energy, 3 Main, Oak Ridge TN 37830

51-53. Gary Riner, U.S. Department of Energy, 3 Main, Oak Ridge TN 37830

54. J. T. Sweeney, U.S. Department of Energy, 3 Main, Oak Ridge TN 37830

55. Don Watkins, Waste Isolation Pilot Plant, U.S. Department of Energy, P. O. Box 3090, Carlsbad, NM 88221 